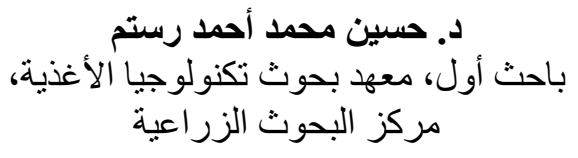

\author{
د. سيده حامد عامر عبدالجواد الدراد

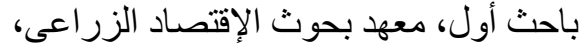

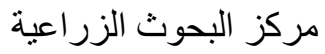

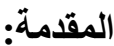

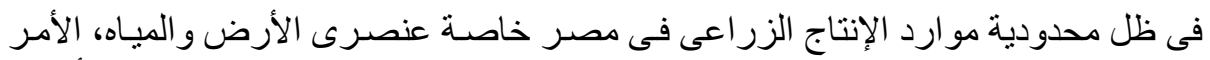

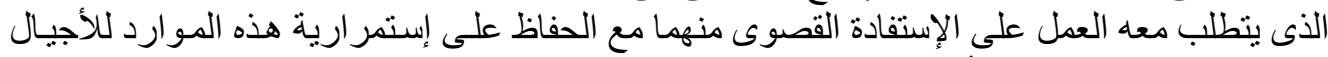

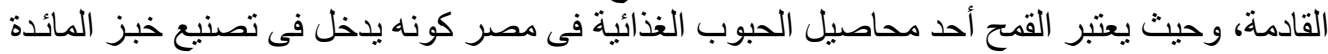

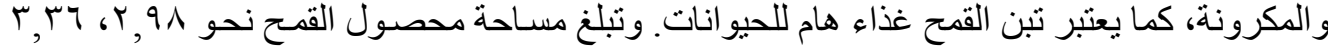

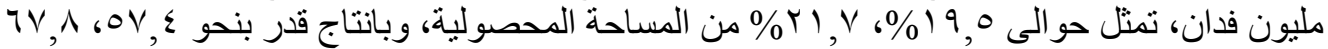

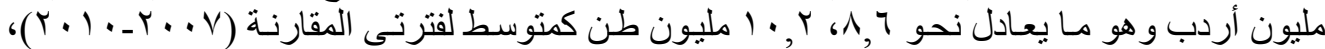

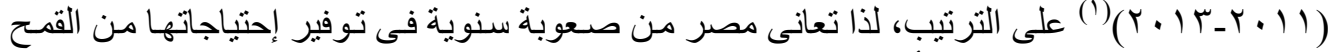

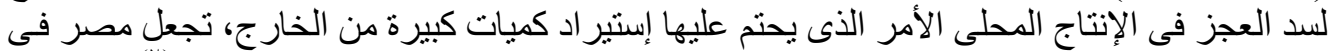

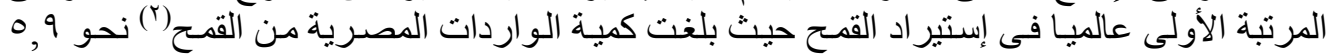

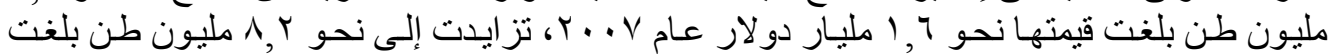

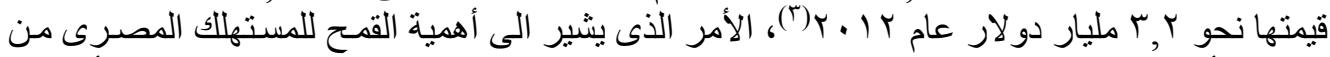

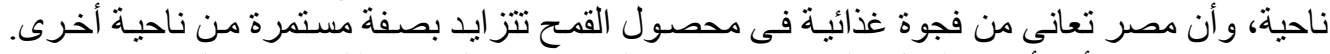

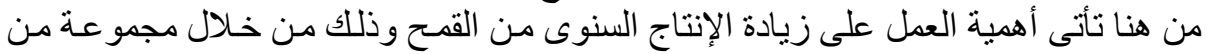

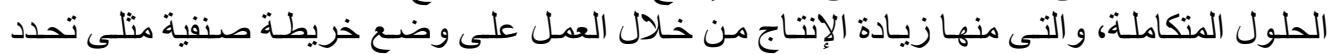

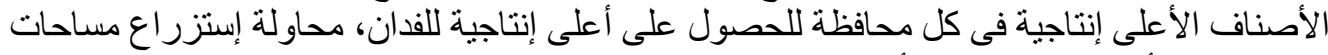

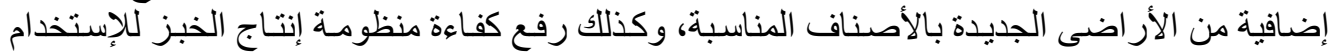

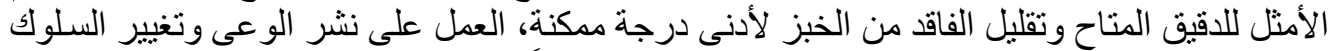

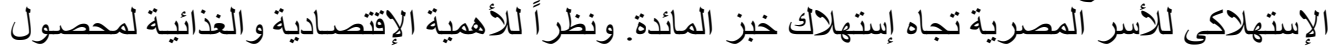

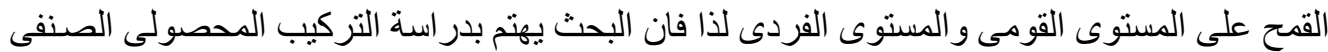

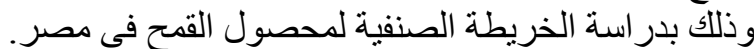

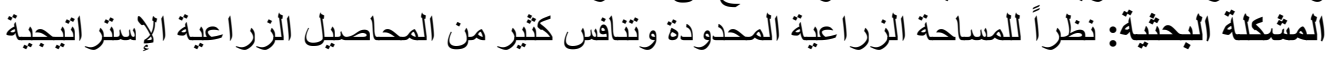

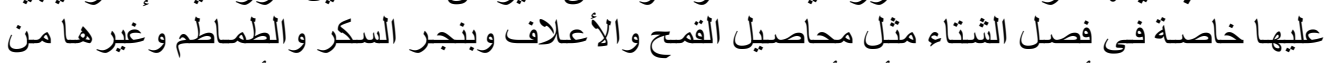

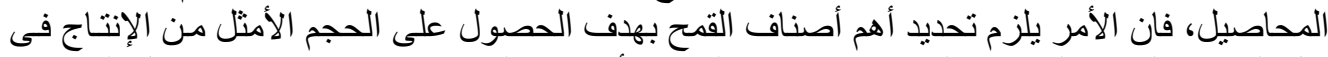

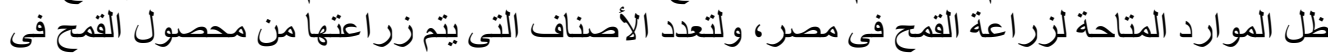

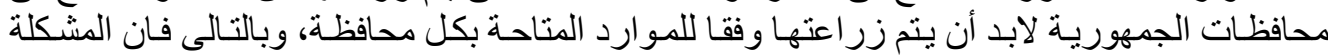

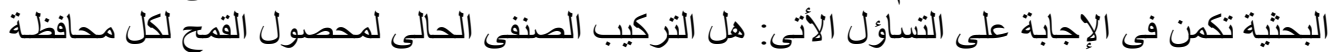

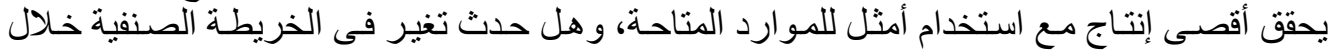

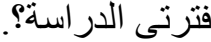

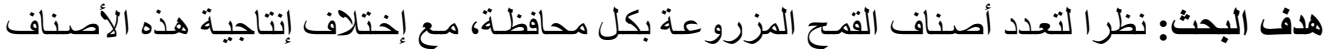

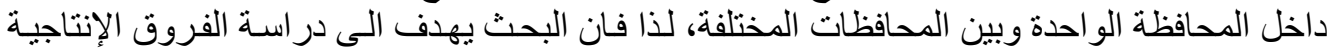

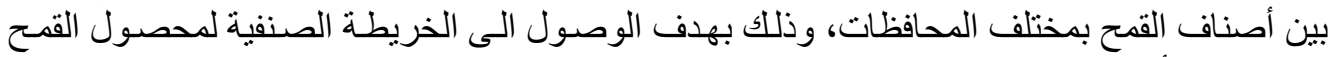

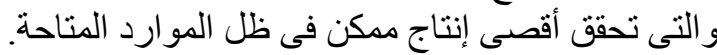
الطريقة البحثية ومصادر البيانات: تعتمد الطريقة البحثية لتحقيق الهدف البحثى على طرئى طيقتين للتحليل كالأتى:

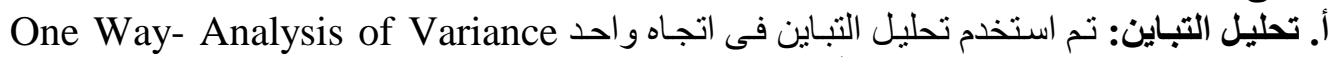

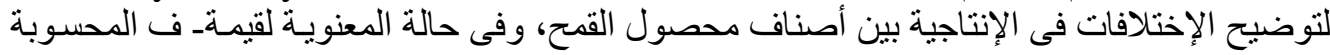

Fayoum J. Agric. Res. \& Dev., Vol. 30, No.1, January, 2016 
يتم المقارنة بين المتوسطات باستخدام إختبار دنكان(ه) لتحديد أى من هذه المتوسطات يكون المسئول

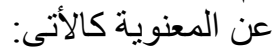

ـ إختبار دنكان: Duncan`s test: ويسمى إختبار أقل مدى معنوى Least Significant Range (L.S.R) - ترتيب المتوسطات تصاعديا ثم ينم تحديد رنبة كل منها. $\mathrm{r}=\left(\mathrm{L}_{\mathrm{i}}-\mathrm{L}_{\mathrm{j}}\right)+1$ where $\mathrm{i}>\mathrm{j}$

L.S.R. $=\mathrm{d}_{(\mathrm{n}-\mathrm{m}, \mathrm{r}, 1-\square)} \cdot \sqrt{\frac{S^{2}}{n}}$

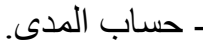
r = متوسـط مربعـات حيث: d d القيمة الحرجة من جداول دنكان. الخطأ.

وفى ضو هُ ذلك يتم تعميم الأصناف الأعلى إنتاجية بكل محافظة.

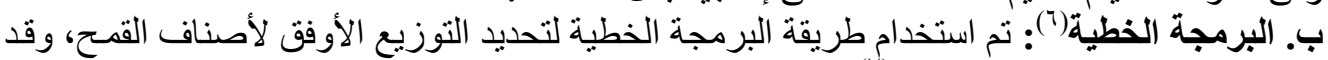

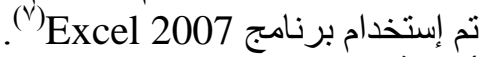

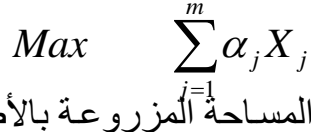

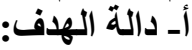
النموذج الأول: تعظيم صافى العائد:

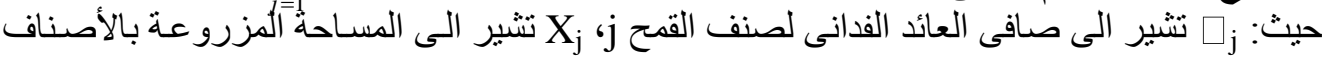

$\operatorname{Min} \quad \sum_{j=1}^{m} \beta_{j} X_{j}$

$\operatorname{Max} \quad \sum_{j=1}^{m} \gamma_{j} X_{j}$

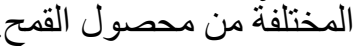
النموذج الثانى: تدنية المقننات المائية:

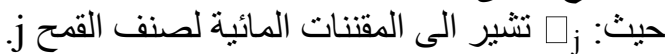

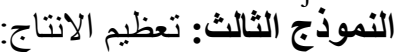

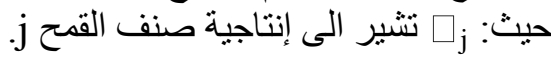

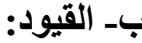
ا ــ القيد الخاص باصل بالمساحة المزروعة بمحصول القمح: ويشمل:

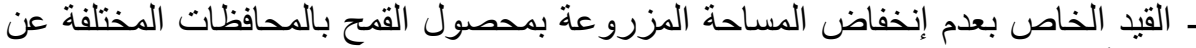

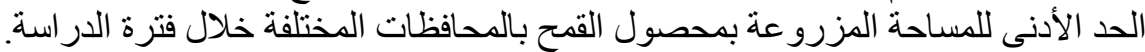
$\sum_{i=1}^{n} X_{i} \geq W_{i}$ rV

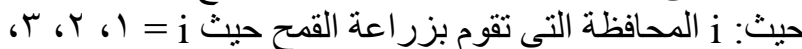
n

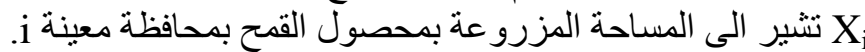

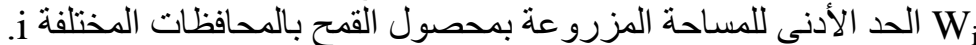

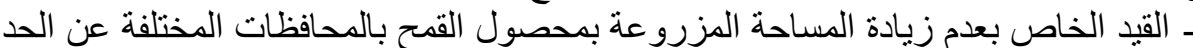

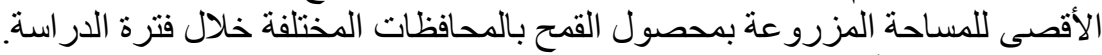
حيث:

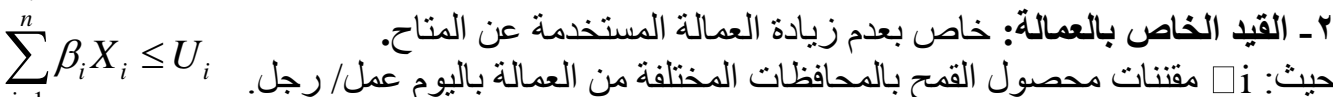

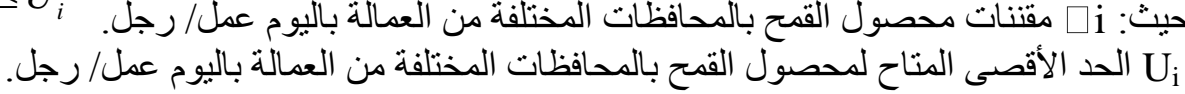

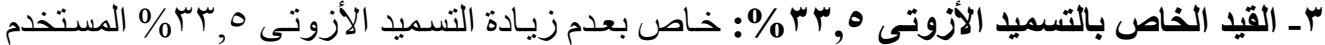

$$
\begin{aligned}
& \sum_{i=1}^{n} d_{i} X_{i} \leq S_{i}
\end{aligned}
$$

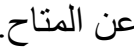

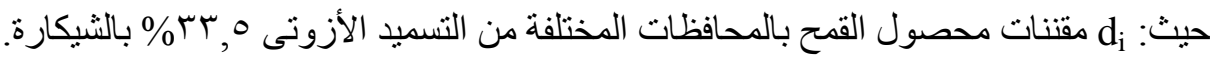

Fayoum J. Agric. Res. \& Dev., Vol. 30, No.1, January, 2016 
$r$

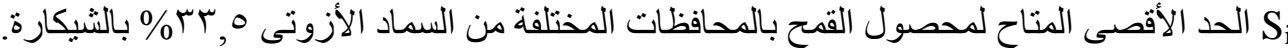

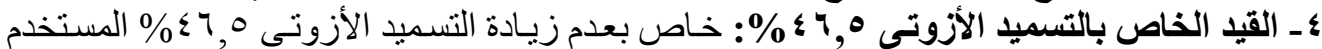

$\sum_{i=1}^{n} e_{i} X_{i} \leq R_{i}$

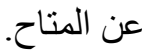

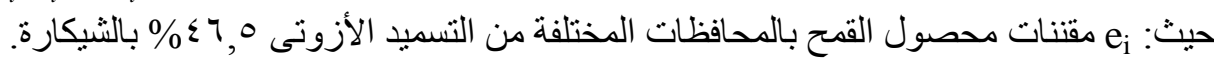

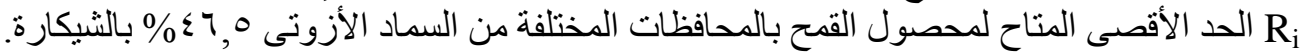

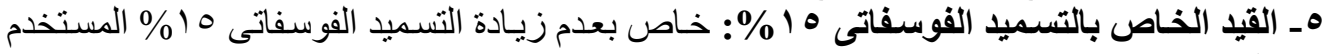
$\sum_{i=1}^{n} f_{i} X_{i} \leq Q_{i}$

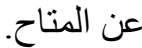

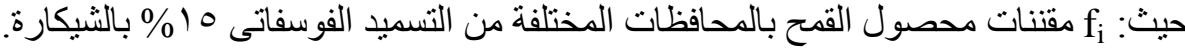

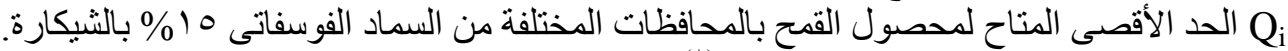

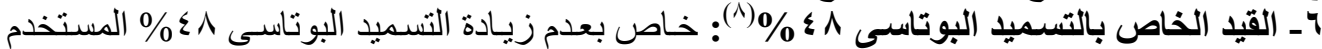

عن المتاح.

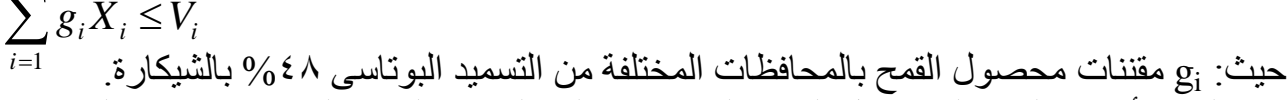

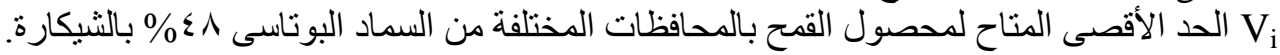

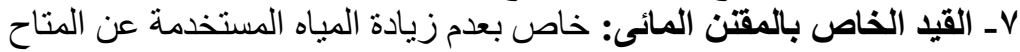

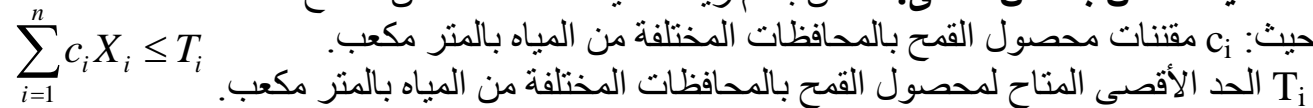

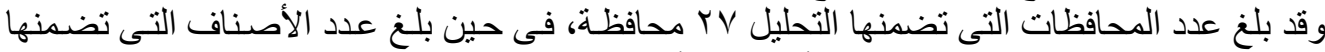

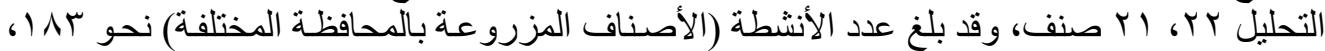

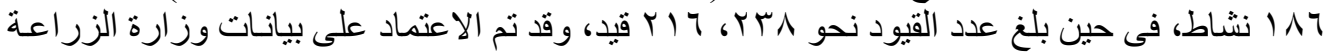

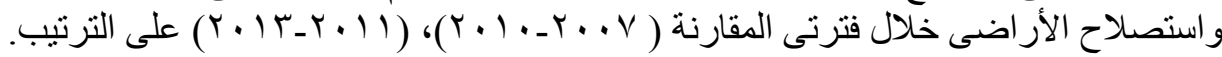

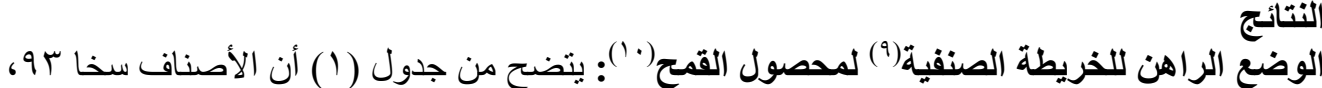

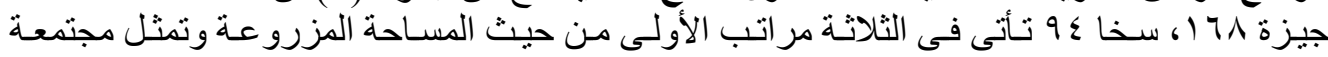

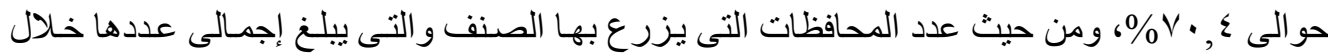

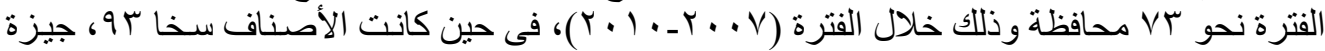

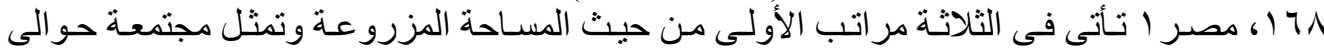

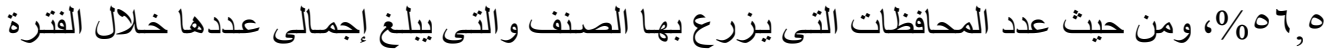

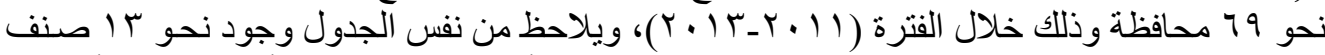

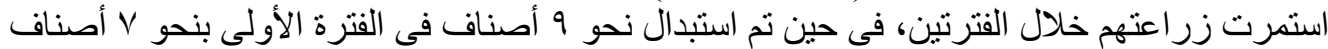

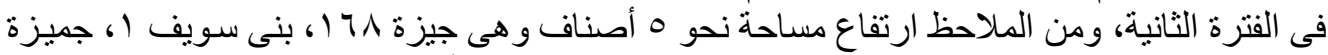
9، سدس ب ا ا، جيزة ـ ـ 17 وذللك فى الفترة الثنانية بالمقارنة بالفترة الأولى.

Fayoum J. Agric. Res. \& Dev., Vol. 30, No.1, January, 2016 
جلول(1): متوسط المساحة المزروعة بأصناف القمح بمحافظات الجمهورية خلال الفترتين . $(r+1 r-r+11)(r+1 \cdot-r+v)$

\begin{tabular}{|c|c|c|c|c|c|c|}
\hline \multicolumn{3}{|c|}{ 2011-2013 } & \multicolumn{3}{|c|}{$2007-2010$} & \multirow{2}{*}{ الصنف } \\
\hline عدد المحافظات & $\%$ & الف فدان & عدد المحافظات & $\%$ & الف فدان & \\
\hline 23 & 22.232 & 746.912 & 24 & 34.061 & 1015.98 & سخا بو9 \\
\hline 24 & 24.904 & 836.688 & 25 & 24.707 & 736.96 & جيزة 171 \\
\hline 15 & 7.552 & 253.715 & 24 & 11.655 & 347.66 & سذا ؟9 \\
\hline 7 & 7.143 & 239.985 & 6 & 7.347 & 219.13 & بنى سويف ا \\
\hline 7 & 3.958 & 132.979 & 10 & 5.891 & 175.73 & سلس \\
\hline 13 & 7.376 & 247.806 & 14 & 5.585 & 166.59 & جميزة9 \\
\hline 4 & 0.821 & 27.585 & 10 & 3.306 & 98.6 & بلدى بل بل \\
\hline 9 & 1.011 & 33.962 & 15 & 1.879 & 56.03 & جميزة.1 \\
\hline 6 & 0.298 & 10.013 & 12 & 1.382 & 41.24 & جميزة' \\
\hline 1 & 0.007 & 0.239 & 11 & 0.558 & 16.64 & سخا 79 \\
\hline 2 & 0.041 & 1.383 & 6 & 0.487 & 14.53 & سذا (17) \\
\hline 18 & 7.307 & 245.503 & 1 & 0.138 & 4.12 & س سـس \\
\hline 1 & 0.136 & 4.574 & 1 & 0.047 & 1.39 & جيزة . 17 \\
\hline- & - & - & 4 & 0.115 & 3.43 & سو هاج ب \\
\hline- & - & - & 5 & 0.109 & 3.25 & بنى سويف r \\
\hline- & - & - & 2 & 0.096 & 2.87 & جيزة 100 \\
\hline - & - & - & 2 & 0.064 & 1.91 & سو هاج 1 \\
\hline- & - & - & 1 & 0.015 & 0.46 & سخام \\
\hline- & - & - & 1 & 0.013 & 0.4 & سدس | س \\
\hline- & - & - & 1 & 0.002 & 0.06 & جميزةه \\
\hline- & - & - & 1 & 0.001 & 0.02 & سخا ش17 \\
\hline - & - & - & 7 & 2.541 & 75.81 & جيزة \&17 \\
\hline 5 & 1.208 & 40.586 & - & - & - & جميزة 11 \\
\hline 3 & 1.686 & 56.646 & - & - & - & بنى سويف 0 \\
\hline 1 & 0.064 & 2.164 & - & - & - & بنى سويف ؛ \\
\hline 22 & 9.373 & 314.916 & - & - & - & مصر 1) \\
\hline 19 & 3.38 & 113.573 & - & - & - & مصر r \\
\hline 1 & 0.019 & 0.638 & - & - & - & شندويل \\
\hline 1 & 0.06 & 2.032 & - & - & - & ايجاسيد \\
\hline 4 & 1.423 & 47.801 & - & - & - & أصناف أخرى \\
\hline & 100 & 3359.7 & - & 100 & 2982.81 & الجملة \\
\hline
\end{tabular}

المصدر: جمعت وحسبت من بيانات وزارة الزراعة واستصلاح الأراضى، الادارة المركزية للإقتصاد الزراعى، نثرة الاحصاء الزر اعى، أعداد مختلفتة.

تحليل التباين: يهنم هذا الجزء بتحليل التباين واختبار الفروق بين إنتاجيـة محصول القمـح وفقا لعنصر

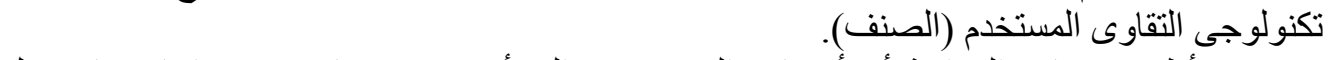

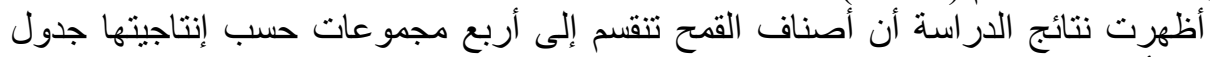

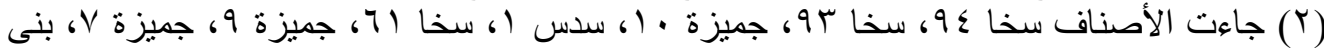

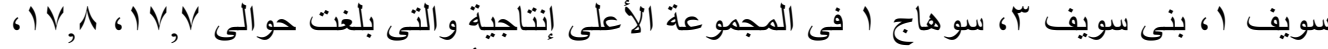

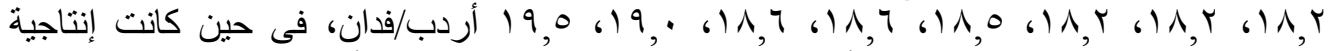

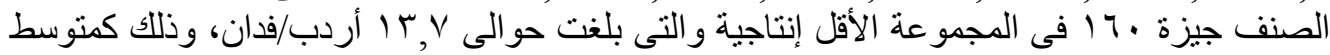

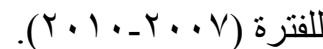

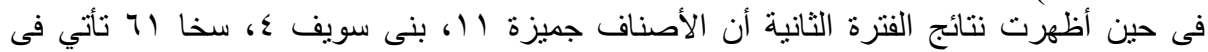

Fayoum J. Agric. Res. \& Dev., Vol. 30, No.1, January, 2016 


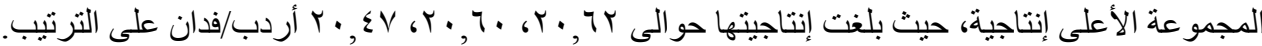

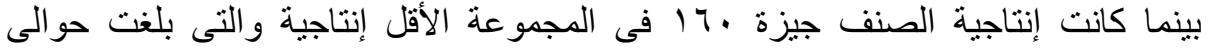

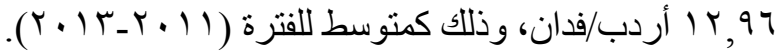

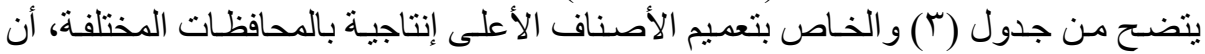

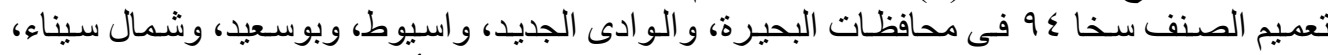

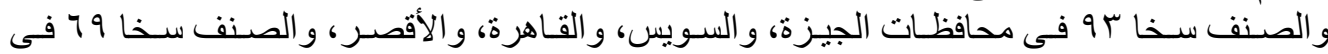

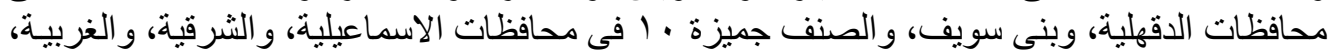

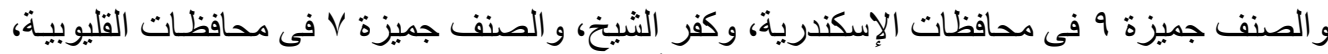

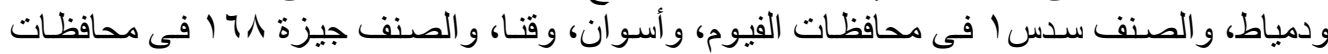

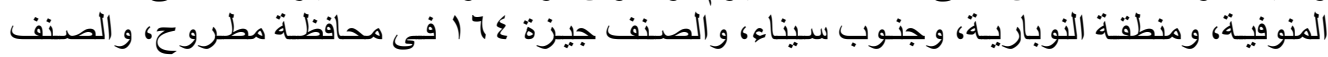

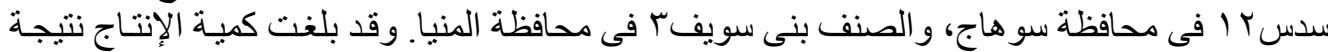

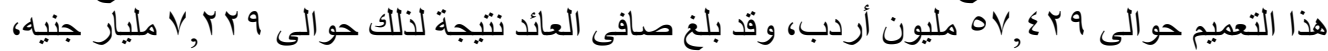

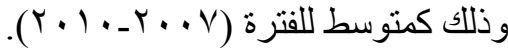

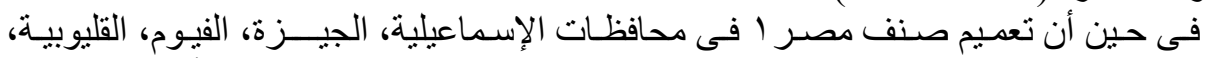

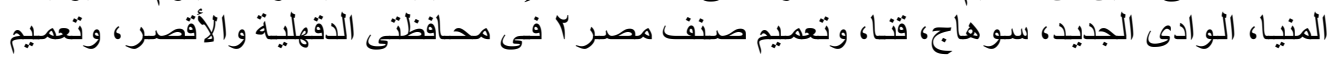

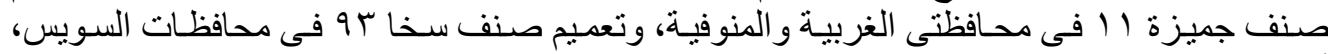

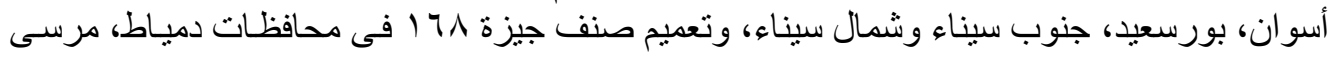

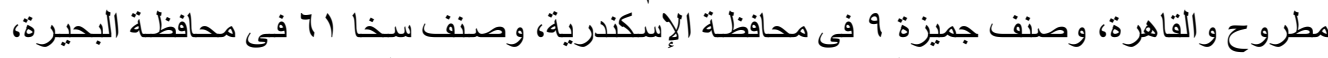

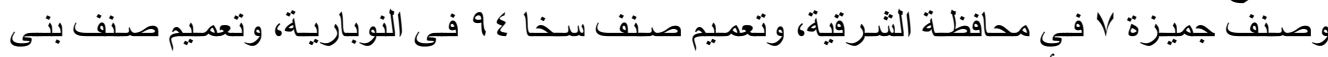

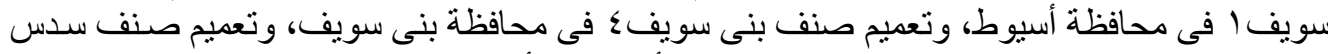

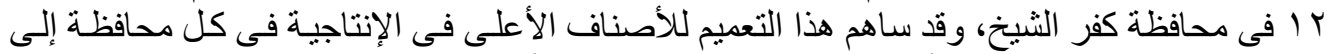

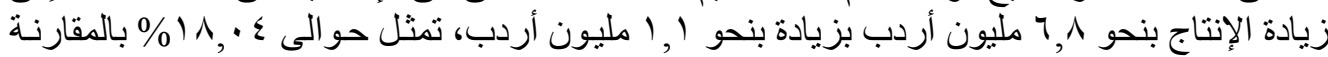

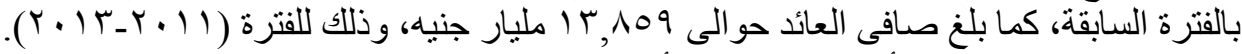

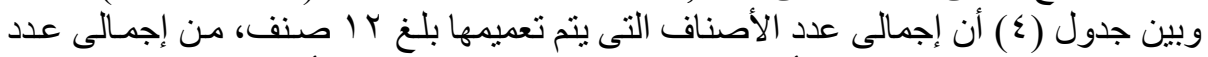

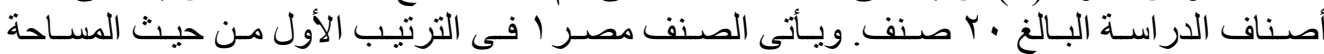

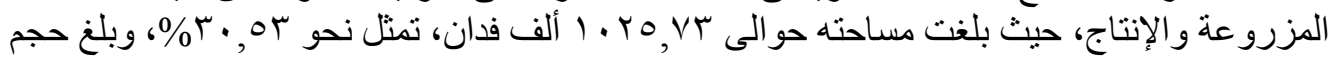

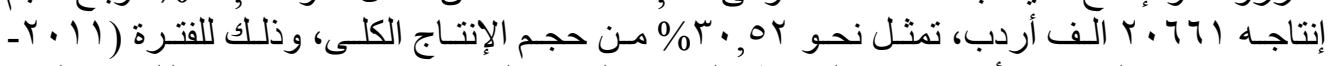

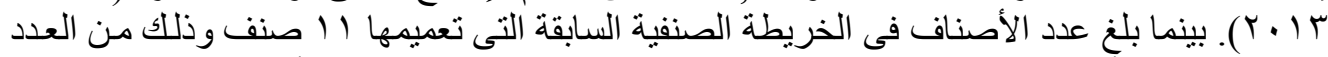

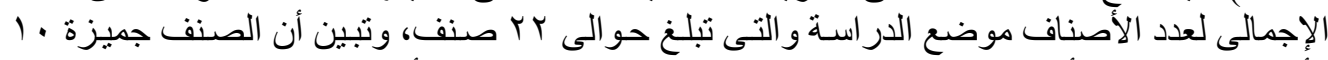

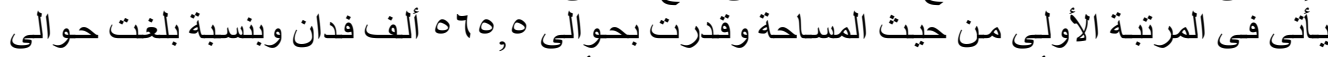

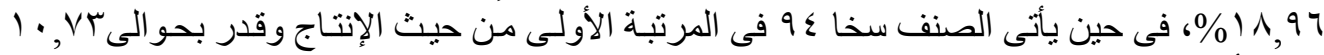

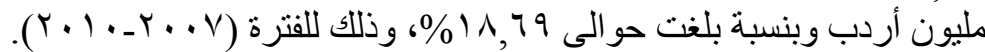

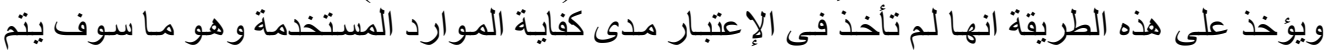
معالجته باستخدام طريقة البرمجة الخطية.

Fayoum J. Agric. Res. \& Dev., Vol. 30, No.1, January, 2016 
جدول (r): إختبار الفروق لأقل مدى معنوى لإنتاجية أصناف محصول القمح خلال الفترتين

\begin{tabular}{|c|c|c|c|c|c|}
\hline & & & & \multicolumn{2}{|c|}{.$(Y+|r-Y+| l)((Y+\mid \cdot-r+V)$} \\
\hline \multicolumn{4}{|c|}{ 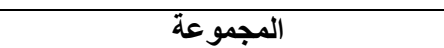 } & \multirow{2}{*}{ أردب/فدانط } & \multirow{2}{*}{ الصنف } \\
\hline 4 & 3 & 2 & 1 & & \\
\hline \multicolumn{6}{|c|}{ 2007-2010 } \\
\hline & & & & 13.7 & 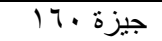 \\
\hline & & & & 14.1 & 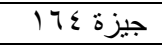 \\
\hline & & & & 14.2 & 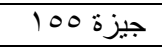 \\
\hline & & & & 15.0 & 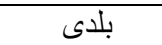 \\
\hline & & & & 16.7 & 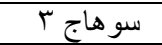 \\
\hline & & & & 17.0 & سخا \\
\hline & & & & 17.5 & 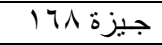 \\
\hline & & & & 17.7 & 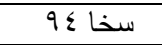 \\
\hline & & & & 17.8 & سخا \\
\hline & & & & 18.2 & جميزة.1. \\
\hline & & & & 18.2 & سدس | ( س \\
\hline & & & & 18.2 & 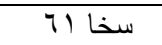 \\
\hline & & & & 18.5 & جميزة9 \\
\hline & & & & 18.6 & جميزة: \\
\hline & & & & 18.6 & بنى سويف \\
\hline & & & & 19.0 & بنى سويف ب \\
\hline & & & & 19.5 & 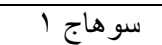 \\
\hline \multicolumn{6}{|c|}{ 2011-2013 } \\
\hline & & & & 12.96 & 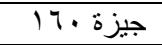 \\
\hline & & & & 15.77 & 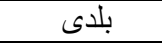 \\
\hline & & & & 17.30 & سـخا بrا \\
\hline & & & & 17.49 & اصناف أخرى \\
\hline & & & & 17.82 & بنى سويف 1 \\
\hline & & & & 17.82 & 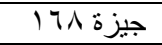 \\
\hline & & & & 18.16 & شندويل \\
\hline & & & & 18.18 & 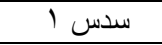 \\
\hline & & & & 18.39 & ايجاسيد \\
\hline & & & & 18.60 & ســا \\
\hline & & & & 18.92 & 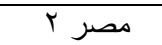 \\
\hline & & & & 18.96 & | سدس ri \\
\hline & & & & 18.98 & جميزة \\
\hline & & & & 18.99 & بنى سويف 0 \\
\hline & & & & 19.33 & جميزة ·. - جميز \\
\hline & & & & 19.36 & سـخا \\
\hline & & & & 19.44 & مصر 1 (مر \\
\hline & & & & 19.60 & 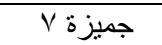 \\
\hline & & & & 20.48 & سـخا لوا \\
\hline & & & & 20.60 & بنى سويف؛ \\
\hline & & & & 20.63 & جميزة ال جميز \\
\hline
\end{tabular}

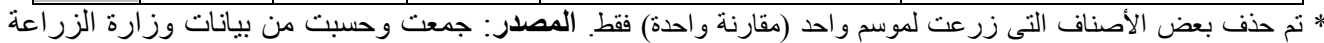
و استصلاح الأراضى، الادارة المركزية للإقتصاد الزراعى، نشرة الاحصاء الزر اعى، أعداد مختلفتة.

Fayoum J. Agric. Res. \& Dev., Vol. 30, No.1, January, 2016 
$\checkmark$

جلول (r): نتائج تعميم الأصناف الأعلى إنتاجية بمحافظات الجمهورية لمحصول القمح كمتوسط

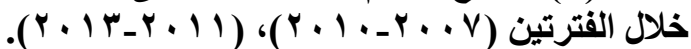

\begin{tabular}{|c|c|c|c|c|c|c|c|c|c|c|c|c|c|}
\hline \multicolumn{7}{|c|}{ 2011-2013 } & \multicolumn{7}{|c|}{$2007-2010$} \\
\hline ملئد المساحة & صافى عائد & الإنتاج & |اردب/فدان & فالف الفة & المحافظة & الصعدف & للمساحسة & | الفدانى عائد & الإنت & أردب/فدانة الإنتاجية & |الفساحة & المحافظة & الصعدف \\
\hline 321.47 & 4.32 & \begin{tabular}{|l|}
1381.14 \\
\end{tabular} & 18.56 & 74.41 & الإسكندرية & جميزة 9 & 183.8 & 2.54 & 1426.9 & 19.8 & 72.2 & الإســكندرية & جميزةه \\
\hline 213.44 & 3.99 & 1009 & 18.86 & 53.49 & الإسماعيلية & مصر 1 & 73.9 & 1.66 & 717 & 16.1 & 44.6 & الإسماعيلية & جميزة.1. \\
\hline 1371.54 & 3.97 & 7506.16 & 21.71 & 345.75 & البحــيرة & ســـا ال7 & \begin{tabular}{|l|}
781.6 \\
\end{tabular} & 2.60 & 6006.7 & 20 & 300.6 & البحــيرة & سخا ؟9 \\
\hline 166.62 & 3.85 & 1031 & 23.84 & 43.24 & الجيـزة & مصر 1 & 103.2 & 2.61 & 791.6 & 20 & 39.5 & الجــــزة & سخا ب9 \\
\hline 1533.7 & 5.24 & 6037.33 & 20.63 & 292.65 & الدقهليــة & مصر r & 826.6 & 2.85 & 6098.8 & 21 & 290.4 & الدقهليــــة & سخا 79 \\
\hline 19.24 & 3.65 & 94.74 & 18 & 5.26 & الســـيس & ســـا بو & 8.7 & 1.78 & 81.3 & 16.6 & 4.9 & الســـيس & سخا 9 \\
\hline \begin{tabular}{|l|}
1937.51 \\
\end{tabular} & 4.5 & 8586.77 & 19.93 & 430.89 & الثــــية & جميزة V & \begin{tabular}{|l|}
819.2 \\
\end{tabular} & 2.20 & 6818.1 & 18.3 & 371.6 & الثـــرقية & جميزة.1. \\
\hline 538.22 & 3.38 & 3425.77 & 21.53 & 159.14 & الغربيــــة & جميزة 11 & 404.8 & 2.71 & 3051.7 & 20.4 & 149.3 & الغربيـــــة & جميزة 1. \\
\hline \begin{tabular}{|l|}
868.12 \\
\end{tabular} & 4.44 & 3881.36 & 19.85 & 195.53 & الفيــوم & مصر 1 & \begin{tabular}{|l|}
306.9 \\
\end{tabular} & 2.00 & 2685.6 & 17.5 & 153.4 & الفيـــوم & سدس \\
\hline 0.26 & 3.28 & 1.4 & 17.48 & 0.08 & القاهـــرة & جيزة 171 & 0.6 & 2.01 & 4.9 & 17.5 & 0.3 & القاهـــرة & سخا 9 \\
\hline \begin{tabular}{|l|}
266.78 \\
\end{tabular} & 4.43 & 1183.02 & 19.65 & 60.21 & القليوبيــة & مصر 1 & 113.2 & 2.29 & 925.3 & 18.7 & 49.5 & القليوبيــة & جميزة Vم \\
\hline 500.38 & 3.66 & 3237.28 & 23.69 & 136.64 & المنوفيــة & جميزة 11 & 311 & 2.85 & 2292 & 21 & 109 & المنوفيـــة & جيزة 117 \\
\hline \begin{tabular}{|l|}
1278.99 \\
\end{tabular} & 5.48 & 5156.17 & 22.08 & 233.56 & المنيـــا & مصر 1 & 545 & 2.63 & 4169.5 & 20.1 & 207.5 & المنيــــا & بنى سويف r \\
\hline 495.6 & 3.68 & 2431.87 & 18.04 & 134.79 & النوباريــة & ســـا 9 & \begin{tabular}{|l|}
277.7 \\
\end{tabular} & 1.90 & 2500.3 & 17.1 & 146.4 & النوبـاريـــة & جيزة 117 \\
\hline 348.12 & 2.39 & 2594.18 & 17.81 & 145.63 & الو ادى الجديد & مصر 1 & 71.5 & 1.32 & 794.9 & 14.7 & 54.1 & الو ادى الجــيد & سخا \&9 \\
\hline 255.17 & 4.39 & 1242.36 & 21.4 & 58.07 & أســــوان & ســـا بو9 & 93 & 2.29 & 760 & 18.7 & 40.6 & أســـــان & سدس \\
\hline 953.93 & 4.68 & 3974.23 & 19.48 & 204 & أســـيوط & بنى سويف 1 & 508.6 & 3.09 & 3621.7 & 22 & 164.5 & أســـوط & سخا 9 \\
\hline 367.24 & 2.69 & 2812.46 & 20.6 & 136.53 & بنى سويف & بنى سويف ع & 345.5 & 2.60 & 2653.2 & 20 & 132.7 & بنى سويف & سخا 79 \\
\hline 56.83 & 3.6 & 281.61 & 17.83 & 15.79 & بور سـعيد & ســـا بـو & 26 & 1.41 & 278 & 15.1 & 18.5 & بور سـعيد & سخا ؟9 \\
\hline 0.17 & 0.97 & 2 & 11.15 & 0.18 & جنوب سيناء & ســخا بـو & -0.01 & -0.04 & 1.3 & 9.1 & 0.1 & جنوب سيناء & جيزة 14 14 \\
\hline 140.01 & 4.67 & 545.66 & 18.21 & 29.97 & دميــاط & جيزة 1717 & 56.2 & 2.10 & 480.1 & 17.9 & 26.8 & دميــــاط & جميزة/ \\
\hline 860.51 & 4.74 & 3581.78 & 19.72 & 181.64 & ســـوهاج & مصر 1 & 566.6 & 3.21 & 3972.7 & 22.5 & 176.6 & سـو هاج & سدس \\
\hline-1.08 & -1.97 & 2.06 & 3.77 & 0.55 & شمال سيناء & ســـا 9 & -16.6 & -1.56 & 29.6 & 2.8 & 10.6 & شمال سـيناء & سخا ؟9 \\
\hline 377.59 & 3.36 & 2224.53 & 19.79 & 112.43 & قت قـــ & مصر 1 & 259.2 & 2.08 & 2223.8 & 17.8 & 124.8 & ق قنـــــ & سدس \\
\hline 826.91 & 3.31 & 4514.76 & 18.07 & 249.85 & كفر الشيخ & سدس YI & 523.3 & 2.25 & 4311.2 & 18.5 & 232.6 & كفر الشيخ & جميزة9 \\
\hline 139.42 & 3.17 & 858.05 & 19.53 & 43.94 & الأقصــــر & مصر r & 48.8 & 2.90 & 356.9 & 21.2 & 16.8 & الأقصر & سخا r9 \\
\hline 22.59 & 1.46 & 192.65 & 12.45 & 15.47 & مطـروح & جيزة 171 & -9.3 & -0.21 & 376 & 8.4 & 44.9 & مطــروح & جيزة عاج 17 \\
\hline 13859.28 & 4.13 & 67789.34 & 20.18 & 3359.7 & ملة & & 7229 & 2.00 & 57429 & 17.5 & 2983 & & الج \\
\hline
\end{tabular}

المصدر: جمعت وحسبت من بيانات وز ارة الزر اعة واستصلاح الأر اضى، الادارة المركزية للإقتصاد

الزراعى، نشرة الاحصاء الزراعي، أعداد مختلفتة.

Fayoum J. Agric. Res. \& Dev., Vol. 30, No.1, January, 2016 
$\Lambda$

جدول (\&): مساحة وإنتاج الأصناف الأعلى إنتاجية المعمدة لمحصول القمح كمتوسط خلال الفترتين

\begin{tabular}{|c|c|c|c|c|}
\hline \multicolumn{5}{|c|}{$2007-2010$} \\
\hline 9.99 & 5738.1 & 10.22 & 304.8 & جميزة9 \\
\hline 18.43 & 10586.8 & 18.96 & 565.5 & جميزة. \\
\hline 18.69 & 10730.9 & 18.38 & 548.3 & سخا §9 \\
\hline 2.15 & 1234.7 & 2.06 & 61.5 & سخا 9 \\
\hline 15.24 & 8752 & 14.18 & 423.1 & سخا 79 \\
\hline 9.87 & 5669.4 & 10.69 & 318.8 & سدس \\
\hline 2.45 & 1405.4 & 2.56 & 76.3 & جميزةV \\
\hline 8.35 & 4793.6 & 8.57 & 255.5 & جيزة 1717 \\
\hline 7.26 & 4169.5 & 6.96 & 207.5 & بنى سويف r \\
\hline 6.92 & 3972.7 & 5.92 & 176.6 & سدسY \\
\hline 0.65 & 376 & 1.51 & 44.9 & جيزة ؛ 11 \\
\hline 100.00 & 57429.1 & 100.00 & 2982.8 & الجملة \\
\hline \multicolumn{5}{|c|}{ 2011-2013 } \\
\hline 5.87 & 3974.23 & 6.07 & 204.00 & بنى سويف 1 \\
\hline 4.15 & 2812.46 & 4.06 & 136.53 & بنى سويف 4 \\
\hline 9.84 & 6663.04 & 8.80 & 295.78 & جميزة 11 \\
\hline 12.68 & 8586.77 & 12.83 & 430.89 & جميزة V \\
\hline 2.04 & 1381.14 & 2.21 & 74.41 & جميزة 9 \\
\hline 1.09 & 739.71 & 1.35 & 45.52 & جيزة 171 \\
\hline 11.09 & 7506.16 & 10.29 & 345.75 & ســـا ال7 \\
\hline 3.51 & 2375.47 & 3.65 & 122.65 & ســــا سو \\
\hline 3.59 & 2431.87 & 4.01 & 134.79 & ســــا 9 \\
\hline 6.67 & 4514.76 & 7.44 & 249.85 & سدس r| \\
\hline 30.52 & 20661.04 & 30.53 & 1025.73 & مصر 1 \\
\hline 8.95 & 6059.62 & 8.74 & 293.80 & مصر r \\
\hline 100.00 & 67706.27 & 100.00 & 3359.70 & الجملة \\
\hline
\end{tabular}

المصدر: جمعت وحسبت من بيانات وزارة الزراعة واستصلاح الأراضى، الادارة المركزية للإقتصاد الزراعى، نشرة

الاحصاء الزر اعى، أعداد مختلفتة.

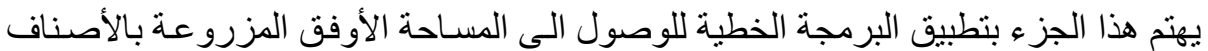

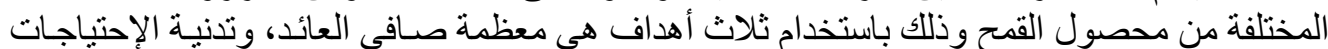

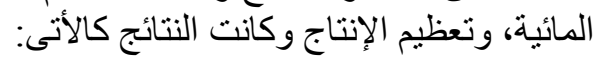

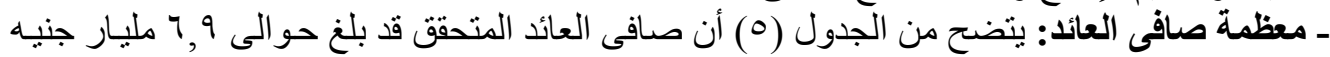

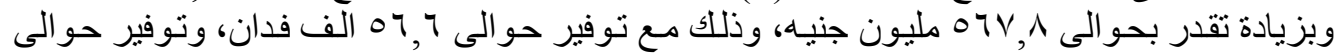

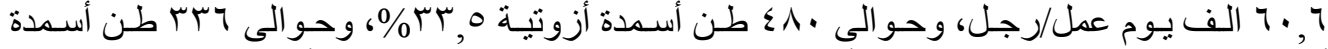

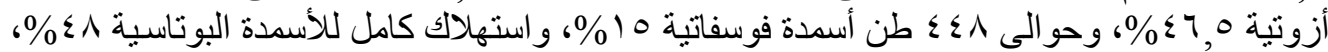

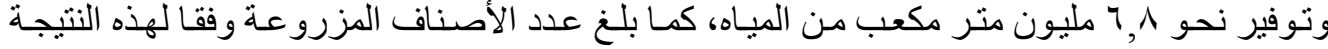

Fayoum J. Agric. Res. \& Dev., Vol. 30, No.1, January, 2016 


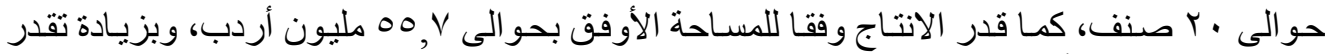

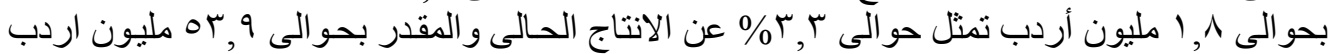

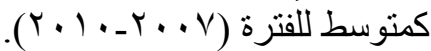

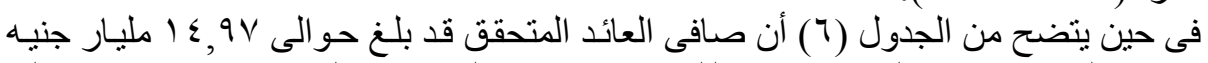

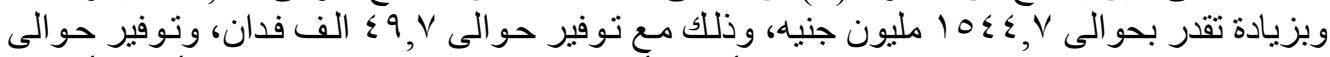

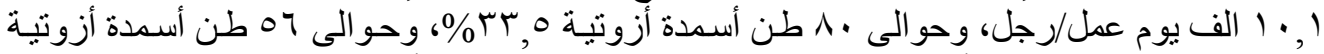

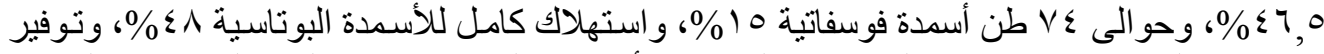

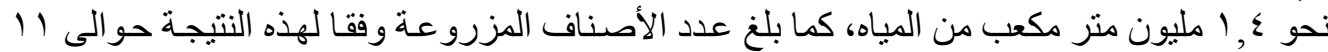

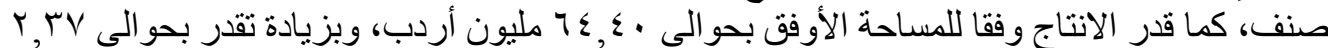

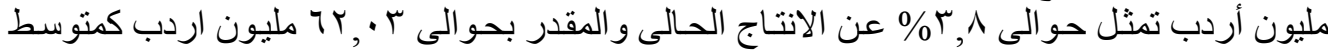

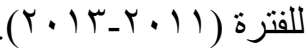
ـ تدنية الاحتياجات المائية: فى ظل الأهمية الكبيرة للمياه، وندرنها، و الإحتبـاج الثنديد لها خاصـة فى الإنى

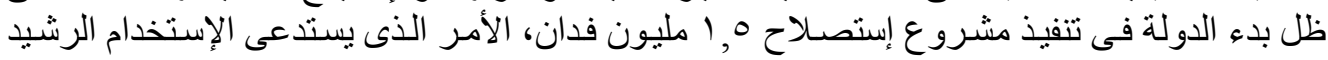

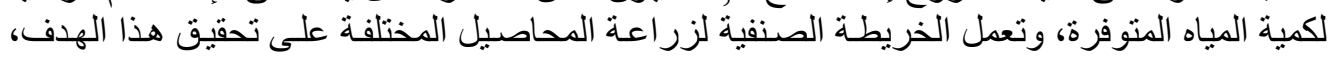

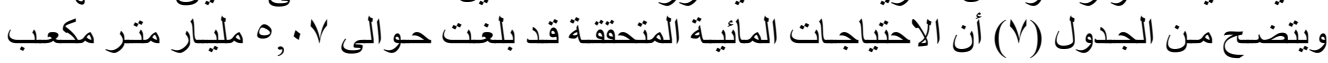

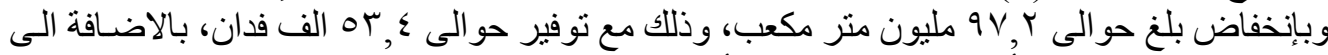

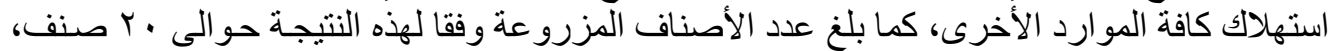

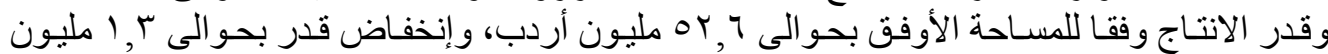

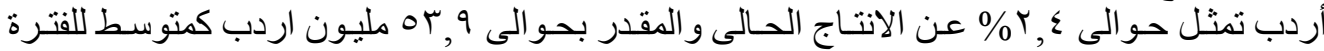
. (r. $(\cdot-r \cdot V)$

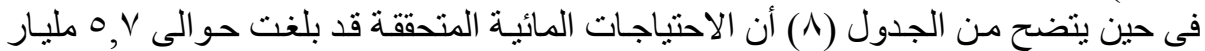

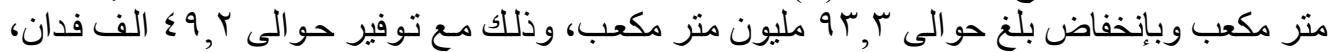

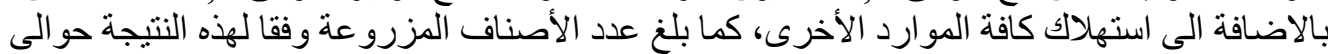

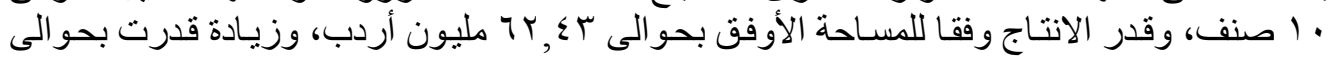

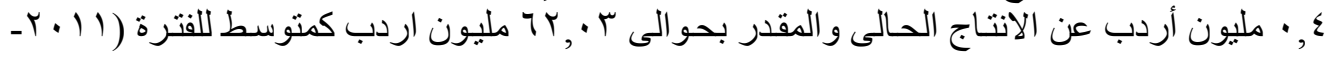
( $($. 1 (T)

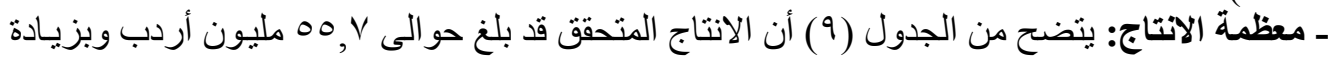

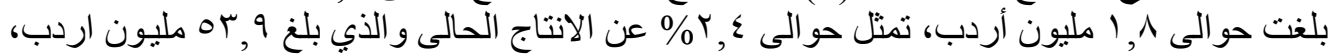

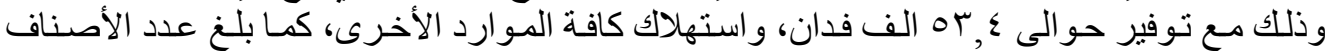

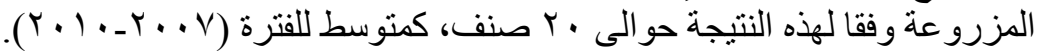

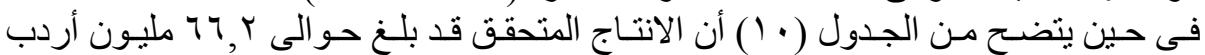

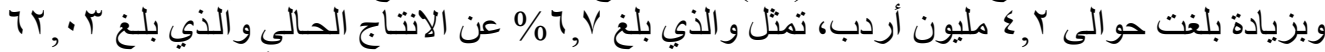

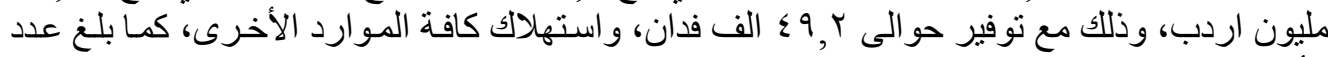

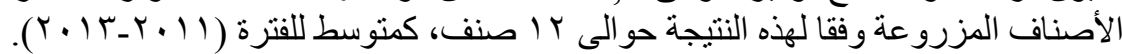

Fayoum J. Agric. Res. \& Dev., Vol. 30, No.1, January, 2016 
1.

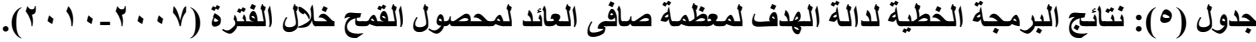

\begin{tabular}{|c|c|c|c|c|c|c|c|c|}
\hline مليون & صليون الأوفق العائد & مليون الحالى العائد & الاتتاج الأوفق & الف فذان & |الفساحة الأوفقى & الف الحالية & المحافظة & الصنف \\
\hline 465.8 & 728.5 & 262.7 & 5687.4 & 184.6 & 288.7 & 104.1 & البحـيرة & سخا بو9 \\
\hline 501.1 & 507.3 & 6.3 & 4210.8 & 227.3 & 230.1 & 2.8 & الثـــرقية & جميزة.1 \\
\hline 438.7 & 497.7 & 59.0 & 4150.4 & 199.9 & 226.8 & 26.9 & كفر الشيخ & جيزة 171 \\
\hline 548.9 & 549.9 & 1.0 & 4057.2 & 192.8 & 193.2 & 0.4 & الدقهليـــة & سخا 79 \\
\hline 126.9 & 470.0 & 343.1 & 3640.6 & 49.9 & 184.8 & 134.9 & المنبــــا & بنى سويف 1 \\
\hline 540.1 & 553.3 & 13.2 & 3861.8 & 168.3 & 172.4 & 4.1 & سـوهاج & سدس \\
\hline 511.2 & 511.7 & 0.5 & 3641.0 & 165.4 & 165.5 & 0.2 & أســـبوط & سخا ؟9 \\
\hline 214.4 & 369.8 & 155.4 & 2911.4 & 86.5 & 149.3 & 62.7 & الغربيــــة & سخا بو9 \\
\hline 208.1 & 277.7 & 69.6 & 2503.4 & 109.7 & 146.4 & 36.7 & النوبـاريـــة & جيزة $17 \wedge$ \\
\hline 89.3 & 281.1 & 191.9 & 2516.4 & 46.5 & 146.3 & 99.8 & الفيـــوم & سخا بو \\
\hline 210.4 & 228.0 & 17.7 & 1954.4 & 101.3 & 109.8 & 8.5 & ق & سدس \\
\hline 297.5 & 310.9 & 13.4 & 2289.0 & 104.3 & 109 & 4.7 & المنوفيــــة & جيزة 171 \\
\hline 204.0 & 271.0 & 67.0 & 2013.4 & 72.9 & 96.8 & 23.9 & الدقهليـــة & جميزة9 \\
\hline 77.7 & 154.3 & 76.5 & 1342.3 & 38.7 & 76.7 & 38 & الثنــرقية & سخا ؟9 \\
\hline 117.0 & 166.8 & 49.8 & 1325.9 & 48.2 & 68.7 & 20.5 & بنى سويف & جيزة 1717 \\
\hline-298.7 & 122.3 & 421.0 & 1094.4 & -156.3 & 64 & 220.3 & الثـــرقية & سخا بو9 \\
\hline 139.8 & 141.2 & 1.4 & 1150.1 & 60.9 & 61.5 & 0.6 & بنى سويف & بلدى بل \\
\hline 75.6 & 108.2 & 32.6 & 901.6 & 34.2 & 49 & 14.8 & القليوبيــة & سخا بو9 \\
\hline 32.2 & 59.8 & 27.6 & 668.7 & 24.7 & 45.8 & 21.2 & الو ادى الجديد & جيزة 171 \\
\hline 0.0 & -9.3 & -9.3 & 377.2 & 0 & 44.9 & 44.9 & مطــروح & جيزة عا 17 \\
\hline 39.4 & 70.7 & 31.3 & 688.0 & 24 & 43 & 19 & الإسماعيلية & سخا بو \\
\hline 87.1 & 100.0 & 12.9 & 766.0 & 33.3 & 38.3 & 4.9 & الجـــيزة & سخا بو \\
\hline 56.5 & 81.5 & 25.0 & 648.5 & 23.3 & 33.6 & 10.3 & الإســكندرية & جميزة \\
\hline 71.9 & 72.6 & 0.7 & 592.8 & 31.4 & 31.7 & 0.3 & أســــوان & سدس \\
\hline 68.2 & 77.8 & 9.6 & 605.9 & 26.8 & 30.6 & 3.8 & الإســكندرية & جميزة9 \\
\hline 37.3 & 55.6 & 18.3 & 476.1 & 17.8 & 26.6 & 8.7 & دميـــاط & سخا بو \\
\hline 4.0 & 48.9 & 44.9 & 386.1 & 1.6 & 19.9 & 18.3 & المنيـــا & سخا بو \\
\hline 1.1 & 24.4 & 23.3 & 262.5 & 0.8 & 17.5 & 16.7 & بور سـيديد & سخا 9 \\
\hline 40.1 & 45.3 & 5.3 & 330.7 & 13.8 & 15.6 & 1.8 & الأقصر & سخا بو9 \\
\hline-157.2 & 12.6 & 169.8 & 112.9 & -83 & 6.6 & 89.6 & ق ت & جيزة 171 \\
\hline-50.3 & 12.2 & 62.5 & 108.4 & -26.1 & 6.3 & 32.4 & الفيـــوم & جيزة 171 \\
\hline-8.7 & 12.5 & 21.2 & 103.6 & -3.9 & 5.6 & 9.5 & كفر الثـيخ & سخا /7 \\
\hline-0.5 & 5.6 & 6.1 & 64.8 & -0.4 & 4.5 & 4.9 & الو ادى الجديد & جيزة ع 17 \\
\hline 4.4 & 7.0 & 2.6 & 66.4 & 2.5 & 4 & 1.5 & الســـيس & سخا بو \\
\hline 0.2 & 4.7 & 4.5 & 46.4 & 0.1 & 2.9 & 2.7 & قن & جيزة 100 \\
\hline 2.0 & 3.1 & 1.1 & 35.3 & 1.5 & 2.4 & 0.8 & الو ادى الجـديد & سو هاج ب \\
\hline 4.9 & 5.9 & 1.1 & 46.2 & 1.9 & 2.3 & 0.4 & المنيــــا & بنى سويف r \\
\hline 11.2 & -3.7 & -14.9 & 4.2 & -6.4 & 2.1 & 8.5 & شمال سـيناء & بلدى \\
\hline 4.9 & 5.4 & 0.5 & 39.9 & 1.7 & 1.9 & 0.2 & أســيوط & سو هاج 1 \\
\hline 0.0 & 0.6 & 0.6 & 7.5 & 0 & 0.5 & 0.5 & الثــرقية & سخاء \\
\hline 0.0 & 1.0 & 1.0 & 7.7 & 0 & 0.4 & 0.4 & بنى سويف & سدسء \\
\hline 0.0 & 0.0 & 0.0 & 0.9 & 0 & 0.1 & 0 & جنوب سيناء & جبزة 171 \\
\hline 0.1 & 0.3 & 0.1 & 1.8 & 0.1 & 0.1 & 0.1 & القاهـــرة & سخا \\
\hline 0.0 & 0.2 & 0.2 & 2.0 & 0 & 0.1 & 0.1 & البحــيرة & جميزة| \\
\hline-4148.8 & 0.0 & 4148.8 & 0.0 & 0 & 0 & 1877.4 & \multicolumn{2}{|c|}{ الأصناف الاخرى } \\
\hline 567.8 & 6944.6 & 6376.8 & 55701.7 & -56.6 & 2926.2 & 2982.8 & \multicolumn{2}{|c|}{ جملة } \\
\hline
\end{tabular}

المصدر: جمعت وحسبت من بيانات وزارة الزراعة واستصلاح الأراضى، الادارة المركزية للإقتصاد الزراعى، نشرة الاحصاء الزر اعى، أعداد مختلفتة.

Fayoum J. Agric. Res. \& Dev., Vol. 30, No.1, January, 2016 
11

جدول (†): نتائج البرمجة الخطية لدالة الهدف لمعظمة صافى العائد لمحصول القمح خلال الفترة . ( $r \cdot \mid r-Y \cdot 11)$

\begin{tabular}{|c|c|c|c|c|c|c|c|c|}
\hline مليون جنيه & مليون الأوفي العائد & | ملافى العائد & الأف الأتقاج & |الف فذان & الأفساحة & الف المالية & المحافظة & الصنف \\
\hline 67.6 & 138.7 & 71.0 & 541.8 & 14.5 & 29.7 & 15.2 & دميــاط & جيزة 17 17 \\
\hline 0.0 & 0.3 & 0.3 & 1.4 & 0.0 & 0.1 & 0.1 & القاهـــرة & جيزة 171 \\
\hline 3.8 & 168.6 & 164.8 & 744.8 & 1.0 & 43.5 & 42.5 & الأقصــــر & جيزة 171 \\
\hline 65.3 & 268.0 & 202.7 & 917.3 & 13.8 & 56.8 & 42.9 & أســـــان & جيزة 171 \\
\hline 0.9 & 23.5 & 22.6 & 192.8 & 0.6 & 16.1 & 15.5 & مطــروح & جيزة 141 \\
\hline 0.0 & 56.8 & 56.8 & 281.5 & 0.0 & 15.8 & 15.8 & بور سـعبد & ســـا بـ \\
\hline 13.2 & 18.0 & 4.8 & 89.6 & 3.6 & 4.9 & 1.3 & الســويس & ســـا بـو \\
\hline 1.0 & 0.0 & -1.1 & 0.0 & -0.5 & 0.0 & 0.5 & شمال سيناء & ســـا 9 و \\
\hline 0.2 & 0.4 & 0.2 & 4.0 & 0.2 & 0.4 & 0.2 & جنوب سيناء & ســـا ra \\
\hline 378.7 & 493.9 & 115.1 & 2431.6 & 103.0 & 134.3 & 31.3 & النوباريــة & ســـا 9 وسـا \\
\hline 308.5 & 340.3 & 31.8 & 1503.6 & 71.4 & 78.8 & 7.4 & |الإسكندرية & جميزة 9 \\
\hline 173.5 & 183.7 & 10.2 & 850.7 & 40.7 & 43.1 & 2.4 & الجيـزة & جمبزة · 1 \\
\hline 1916.5 & 1921.5 & 5.0 & 8794.6 & 426.2 & 427.3 & 1.1 & الثـرقية & جميزة V \\
\hline 467.8 & 502.2 & 34.4 & 2033.3 & 103.7 & 111.3 & 7.6 & ق قن & سدس I \\
\hline 736.1 & 796.7 & 60.5 & 4323.9 & 222.4 & 240.7 & 18.3 & كفر الثـيخ & سدس r| \\
\hline 620.6 & 697.3 & 76.7 & 3049.2 & 121.2 & 136.2 & 15.0 & المنوفيــة & سدس r| \\
\hline 758.5 & 958.8 & 200.4 & 3990.5 & 162.2 & 205.0 & 42.9 & أســيوط & بنى سويف 1 \\
\hline 1705.2 & 1883.7 & 178.5 & 6972.0 & 308.1 & 340.4 & 32.2 & البحـيرة & مصر 1 \\
\hline 680.3 & 738.3 & 58.0 & 3227.5 & 142.8 & 154.9 & 12.2 & الغربيـــة & مصر 1 \\
\hline 170.0 & 210.8 & 40.8 & 971.5 & 42.6 & 52.8 & 10.2 & |الإسماعيلية & مصر I \\
\hline 220.4 & 256.8 & 36.4 & 1125.9 & 49.8 & 58.0 & 8.2 & القليوبيـــة & مصر 1 \\
\hline 464.0 & 487.6 & 23.7 & 2624.2 & 129.8 & 136.4 & 6.6 & بنى سويف & مصر I \\
\hline 791.4 & 857.2 & 65.8 & 3612.4 & 178.2 & 193.1 & 14.8 & الفيــوم & مصر 1 \\
\hline 1225.0 & 1260.7 & 35.8 & 4701.7 & 223.7 & 230.2 & 6.5 & المنيــــا & مصر 1 \\
\hline 824.8 & 852.0 & 27.2 & 3475.8 & 174.1 & 179.8 & 5.7 & ســـوهاج & مصر 1 \\
\hline 238.6 & 289.6 & 51.1 & 2094.9 & 99.8 & 121.2 & 21.4 & |الو ادى الجديد & مصر 1 \\
\hline 1526.0 & 1567.8 & 41.8 & 5844.8 & 291.2 & 299.2 & 8.0 & الدقهليـــة & مصر r \\
\hline-11813.5 & 0.0 & 11813.5 & 0.0 & 0.0 & 0.0 & 2973.9 & \multicolumn{2}{|c|}{ الأصناف الاخرى } \\
\hline 1544.7 & 14973.2 & 13428.5 & 64401.5 & -49.7 & 3310.0 & 3359.7 & \multicolumn{2}{|c|}{ الجملة } \\
\hline
\end{tabular}

المصدر: جمعت وحسبت من بيانات وزارة الزراعة واستصلاح الأراضى، الادارة المركزية للإقتصاد الزراعى، نشرة الاحصاء الزر اعى، أعداد مختلفتة.

Fayoum J. Agric. Res. \& Dev., Vol. 30, No.1, January, 2016 
ir

جدول (V): نتائج البرمجة الخطية لدالة الهرف لتدنية الاحتياجات المائية لمحصول القمح خلال

\begin{tabular}{|c|c|c|c|c|c|c|c|c|}
\hline مليون متر & |الاحتياجات | المائية & الحتالية مليونية الاحتياتي & |الاتتاج الأوفث & فلفران الف & الف فلأوفاحة & الف فالية المة & المحافظة & الصنف \\
\hline 220.3 & 450.1 & 229.8 & 816.0 & 142 & 290 & 148.1 & الدقةهليـــة & سخا بـ9 \\
\hline 345.3 & 448.1 & 102.8 & 10.6 & 222.5 & 288.7 & 66.3 & البحــيرة & سخا \&9 \\
\hline 361.7 & 366.1 & 4.4 & 61.6 & 233.1 & 235.9 & 2.8 & الثــرقية & جميزة • \\
\hline 146.2 & 360.7 & 214.5 & 3281.9 & 94.2 & 232.4 & 138.2 & كفر الشيخ & سخا 9 \\
\hline 356.8 & 358.1 & 1.3 & 753.6 & 167.7 & 168.3 & 0.6 & سـوهاج & بنى سويف 1 \\
\hline 202.6 & 258.3 & 55.7 & 39.1 & 117.9 & 150.4 & 32.4 & الفيــوم & جيزة 171 \\
\hline 173.3 & 200.9 & 27.6 & 3798.0 & 111.7 & 129.4 & 17.8 & الغربيـــــة & سخا ؟9 \\
\hline 172.3 & 197.7 & 25.4 & 326.2 & 111 & 127.4 & 16.4 & الثــرقية & جميزة9 \\
\hline 165.9 & 270.5 & 104.6 & 281.2 & 78 & 127.1 & 49.1 & النوبـاريــة & سخا r9 \\
\hline 63.2 & 253.9 & 190.7 & 2.0 & 29.7 & 119.3 & 89.6 & ق قتــــا & جيزة 171 \\
\hline 91.6 & 169.1 & 77.5 & 2255.0 & 59 & 109 & 50 & المنوفيـــة & سخا بو \\
\hline 225.6 & 227.0 & 1.4 & 35.7 & 106 & 106.7 & 0.6 & أســيوط & سو هاج ب \\
\hline 146.9 & 178.3 & 31.4 & 377.2 & 85.5 & 103.8 & 18.3 & المنيــــا & سخا 979 \\
\hline 160.1 & 177.3 & 17.2 & 45.0 & 93.2 & 103.2 & 10 & المنيــــا & سدس \\
\hline 128.4 & 163.6 & 35.2 & 2586.9 & 74.7 & 95.2 & 20.5 & بنى سويف & جبزة 171 \\
\hline 69.7 & 99.5 & 29.8 & 2040.0 & 44.9 & 64.1 & 19.2 & الإســكندرية & جيزة 171 \\
\hline 108.2 & 115.7 & 7.5 & 1837.4 & 50.8 & 54.4 & 3.5 & أســـيوط & بلدى \\
\hline 110.0 & 112.2 & 2.2 & 1115.3 & 51.7 & 52.7 & 1 & الو ادى الجـديد & بنى سويف 1 \\
\hline 64.4 & 76.1 & 11.7 & 886.9 & 41.5 & 49 & 7.6 & القليوبيــة & جيزة 171 \\
\hline 0.0 & 95.5 & 95.5 & 653.6 & 0 & 44.9 & 44.9 & مطـــروح & جيزة § 17 \\
\hline 55.6 & 66.7 & 11.1 & 437.5 & 35.8 & 43 & 7.1 & الإسماعيلية & جيزة 171 \\
\hline 64.5 & 65.7 & 1.2 & 470.8 & 37.6 & 38.3 & 0.7 & الجــــزة & سدس \\
\hline 60.1 & 60.8 & 0.7 & 259.0 & 35 & 35.4 & 0.4 & بنى سويف & سدسء \\
\hline 12.5 & 67.5 & 55.0 & 229.1 & 5.9 & 31.7 & 25.8 & أســــوان & جبزة 114 \\
\hline 24.0 & 41.2 & 17.2 & 1.8 & 15.5 & 26.6 & 11.1 & دميـــاط & جيزة 171 \\
\hline 34.1 & 41.2 & 7.0 & 0.9 & 16 & 19.3 & 3.3 & النوباريــــة & جميزة:V \\
\hline 26.5 & 27.1 & 0.7 & 105.3 & 17 & 17.5 & 0.4 & بور ســيد & جبزة 171 \\
\hline 10.6 & 22.1 & 11.5 & 106.5 & 6.8 & 14.2 & 7.4 & الغربيــــة & جميزة \\
\hline-0.1 & 27.2 & 27.2 & 5452.0 & 0 & 12.8 & 12.8 & الأقصر & جيزة 111 \\
\hline 10.6 & 11.7 & 1.1 & 4206.4 & 6.8 & 7.5 & 0.7 & الثثـرقية & سخا 79 \\
\hline 4.9 & 8.7 & 3.8 & 2097.2 & 3.2 & 5.6 & 2.4 & الغربيــــة & سخا /7 \\
\hline-6.8 & 11.3 & 18.1 & 2289.0 & -3.2 & 5.3 & 8.5 & شمال سـيناء & بلدى \\
\hline 9.6 & 9.6 & 0.0 & 2013.7 & 4.5 & 4.5 & 0 & أســيوط & جيزة §؟1 \\
\hline 0.0 & 8.8 & 8.8 & 5774.0 & 0 & 4.1 & 4.1 & سـوهاج & سدس با \\
\hline 6.1 & 6.1 & 0.0 & 2562.1 & 3.9 & 4 & 0 & الســـيس & بلدى \\
\hline 5.8 & 6.1 & 0.3 & 7.5 & 2.7 & 2.9 & 0.1 & الأقصر & جيزة 100 \\
\hline 3.2 & 3.9 & 0.6 & 1991.8 & 1.9 & 2.3 & 0.4 & الفيــوم & بنى سويف r \\
\hline 3.7 & 4.1 & 0.4 & 743.0 & 1.7 & 1.9 & 0.2 & أســيوط & سو هاج 1 \\
\hline 0.0 & 0.7 & 0.7 & 92.3 & 0 & 0.5 & 0.5 & الثـــرقية & سخاء \\
\hline 0.0 & 0.2 & 0.2 & 683.2 & 0 & 0.1 & 0.1 & القاهــــــة & جبزة 171 \\
\hline 0.0 & 0.1 & 0.1 & 39.9 & 0 & 0.1 & 0 & جنوب سيناء & جبزة 171 \\
\hline 0.0 & 0.1 & 0.1 & 1856.6 & 0 & 0.1 & 0.1 & البحـيرة & جميزةٌ \\
\hline-3734.8 & 0 & 3734.8 & 0.0 & 0 & 0 & 2159.8 & \multicolumn{2}{|c|}{ الأصناف الاخرى } \\
\hline-97.2 & 6 & 5166.8 & .5 & -53.4 & 2929.4 & 8 & $\alpha$ & \\
\hline
\end{tabular}

المصدر: جمعت وحسبت من بيانات وزارة الزراعة واستصلاح الأراضى، الادارة المركزية للإقتصاد الزراعى، نشرة الاحصاء الزر اعى، أعداد مختلفتة.

Fayoum J. Agric. Res. \& Dev., Vol. 30, No.1, January, 2016 
ir

جدول (^): نتائج البرمجة الخطية لدالة الهدف لتدنية الاحتياجات المائية لمحصول القمح خلال

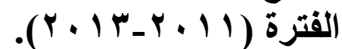

\begin{tabular}{|c|c|c|c|c|c|c|c|c|}
\hline مليون متر & مليون متر مكعبية الأوفت & مليون متية الاحيالية & الف الأوفقت & الف فذان & الألوفن الفة & الف الحالية & المحافظة & الصنف \\
\hline 295.8 & 373.6 & 77.8 & 4360.3 & 190.6 & 240.7 & 50.1 & كفر الثشبخ & جيزة 171 \\
\hline 6.7 & 7.6 & 0.9 & 80.5 & 4.3 & 4.9 & 0.6 & النسـويس & جيزة 171 \\
\hline 0.0 & 0.1 & 0.1 & 1.4 & 0.0 & 0.1 & 0.1 & القاهـــرة & جيزة 171 \\
\hline 335.4 & 436.3 & 100.9 & 3860.7 & \begin{tabular}{|l|}
157.6 \\
\end{tabular} & 205.0 & 47.4 & أســـبوط & جيزة 171 \\
\hline 1.4 & 34.3 & 32.9 & 192.8 & 0.6 & 16.1 & 15.5 & مطـروح & جيزة 1711 \\
\hline 0.0 & 24.5 & 24.5 & 281.5 & 0.0 & 15.8 & 15.8 & بور سـعيد & سـخا بوq \\
\hline 91.8 & 92.5 & 0.7 & 762.0 & 43.1 & 43.5 & 0.3 & الأقصــر & سـخـا 9 و \\
\hline 119.9 & 120.8 & 0.9 & \begin{tabular}{|l|}
1133.4 \\
\end{tabular} & 56.3 & 56.8 & 0.4 & أســــوان & سـخا \\
\hline 0.0 & 1.2 & 1.2 & 1.3 & 0.0 & 0.5 & 0.5 & شمال سيناء & سـخا بـو \\
\hline 0.4 & 0.8 & 0.4 & 4.0 & 0.2 & 0.4 & 0.2 & جنوب سيناء & سـخا 9 و \\
\hline 44.9 & 46.1 & 1.2 & 499.9 & 28.9 & 29.7 & 0.8 & دميــاط & سـخا 9 \\
\hline 609.0 & 663.2 & 54.2 & 7887.9 & \begin{tabular}{|l|}
392.4 \\
\end{tabular} & 427.3 & 34.9 & الثــرقية & ســا 9 \\
\hline 82.2 & 90.0 & 7.8 & 1050.3 & 53.0 & 58.0 & 5.0 & القليوبيــة & سـخا 9 \\
\hline 330.9 & 331.7 & 0.8 & 3601.9 & 192.6 & 193.1 & 0.4 & الفيــوم & جميزة 9 \\
\hline 115.7 & 122.2 & 6.6 & 1472.0 & 74.5 & 78.8 & 4.2 & الإسكندرية & جميزة · 1 \\
\hline 525.7 & 528.3 & 2.5 & 6534.4 & 338.7 & 340.4 & 1.6 & البحـيرة & جميزة: V \\
\hline 209.4 & 211.4 & 2.0 & 2974.0 & \begin{tabular}{|l|}
134.9 \\
\end{tabular} & 136.2 & 1.3 & المنوفيــة & جميزة V \\
\hline 73.9 & 74.1 & 0.2 & 855.0 & 43.0 & 43.1 & 0.1 & الجيـزة & جميزة V \\
\hline 376.8 & 395.5 & 18.8 & 4398.2 & 219.3 & 230.2 & 10.9 & المنيــــا & سدس 1 \\
\hline 220.6 & 236.8 & 16.2 & 2033.3 & \begin{tabular}{|l|}
103.7 \\
\end{tabular} & 111.3 & 7.6 & قت قن & سدس 1 \\
\hline 234.9 & 257.9 & 23.0 & 1737.5 & 110.4 & 121.2 & 10.8 & الو ادى الجديد & بني سويف 1 \\
\hline 221.6 & 240.5 & 18.9 & 3227.5 & 142.8 & 154.9 & 12.2 & الغربيـــة & مصر 1 \\
\hline 409.5 & 464.3 & 54.7 & 6064.5 & 263.9 & 299.2 & 35.3 & الدقهليــة & مصر 1 \\
\hline 370.5 & 382.7 & 12.2 & 3475.8 & 174.1 & 179.8 & 5.7 & سـو هاج & مصر 1 \\
\hline 79.3 & 82.0 & 2.7 & 949.2 & 51.1 & 52.8 & 1.8 & الإسماعيلية & مصر r \\
\hline 228.3 & 234.4 & 6.1 & 2562.9 & \begin{tabular}{|l|}
132.9 \\
\end{tabular} & 136.4 & 3.5 & بنى سويف & مصر r \\
\hline 269.3 & 285.8 & 16.5 & 2424.1 & 126.5 & 134.3 & 7.8 & النوباريــة & مصر r \\
\hline-5347.1 & 0.0 & 5347.1 & 0.0 & 0.0 & 0.0 & 3084.7 & \multicolumn{2}{|c|}{ الأصناف الاخرى } \\
\hline-93.3 & 5738.5 & 5831.8 & 62426.1 & \begin{tabular}{|l|}
-49.2 \\
\end{tabular} & 3310.5 & 3359.7 & \multicolumn{2}{|c|}{ الجملة } \\
\hline
\end{tabular}

المصدر: جمعت وحسبت من بيانات وزارة الزراعة واستصلاح الأراضى، الادارة المركزية للإقتصاد الزراعى، نشرة الاحصاء الزر اعى، أعداد مختلفتة.

Fayoum J. Agric. Res. \& Dev., Vol. 30, No.1, January, 2016 
$1 \varepsilon$

جدول (9): نتائج البرمجة الخطية لدالة الهدف لمعظمة الانتاج لمحصول القمح خلال الفترة

.$(Y \cdot 1 \cdot-r \cdot V)$

\begin{tabular}{|c|c|c|c|c|c|c|c|}
\hline الف اردب & الاتتاج الأوفق & الانتاج اردبالى & |الفرق الف & |المساحة فالأوفق & | متوسطة المساحة & المحافظة & الصنف \\
\hline 3630.5 & 5678 & 2047.4 & 184.6 & 288.7 & 104.1 & البحــيرة & سخا ra \\
\hline 4228.7 & 4280.8 & 52.1 & 230.5 & 233.3 & 2.8 & الثـــرقية & جميزة. \\
\hline 3659.6 & 4152 & 492.4 & 199.9 & 226.8 & 26.9 & كفر الشـيخ & جبزة 171 \\
\hline 4049.5 & 4057.1 & 7.6 & 192.8 & 193.2 & 0.4 & الدقهليــــة & سخا 79 \\
\hline 985.3 & 3649.9 & 2664.5 & 49.9 & 184.8 & 134.9 & المنيـــا & بنى سويف 1 \\
\hline 3786.4 & 3879.2 & 92.8 & 168.3 & 172.4 & 4.1 & ســو هاج & سدس \\
\hline 3640.5 & 3644.1 & 3.6 & 165.4 & 165.6 & 0.2 & أســبوط & سخا ع 9 \\
\hline 853 & 2568.2 & 1715.2 & 49.7 & 149.5 & 99.8 & الفيــوم & سخا ra \\
\hline 1685.5 & 2907.1 & 1221.6 & 86.5 & 149.3 & 62.7 & الغربيــــة & سخا ra \\
\hline 1873.7 & 2500.3 & 626.6 & 109.7 & 146.4 & 36.7 & النوباريــــة & جيزة 171 \\
\hline 1805 & 1956.7 & 151.7 & 101.3 & 109.8 & 8.5 & ق ت & سدس \\
\hline 2192.5 & 2291.5 & 99 & 104.3 & 109 & 4.7 & المنوفيـــة & جبزة 171 \\
\hline 1516.7 & 2014.5 & 497.8 & 72.9 & 96.8 & 23.9 & الدقهليـــة & جميزة9 \\
\hline 678.4 & 1345.9 & 667.5 & 38.7 & 76.7 & 38 & الثـــرقية & سخا \&9 9 \\
\hline 990 & 1385.2 & 395.3 & 51.4 & 71.9 & 20.5 & بنى سويف & جيزة 171 \\
\hline-2732.9 & 1042.1 & 3775 & -159.5 & 60.8 & 220.3 & الثـــرقية & سخا rq9 \\
\hline 1080.7 & 1091.8 & 11.1 & 57.7 & 58.3 & 0.6 & بنى سويف & بلدى بل بل \\
\hline 628.8 & 900.3 & 271.5 & 34.2 & 49 & 14.8 & القليوبيـــة & سخا 9 س \\
\hline 361 & 670.6 & 309.5 & 24.7 & 45.8 & 21.2 & الو ادى الجـديد & جيزة 171 \\
\hline 0 & 376 & 376 & 0 & 44.9 & 44.9 & مطــروح & جيزة ع 17 \\
\hline 384.2 & 689.3 & 305 & 24 & 43 & 19 & الإسماعيلية & سخا 9 \\
\hline 667.6 & 766.8 & 99.1 & 33.3 & 38.3 & 4.9 & الجـــيزة & سخا ra \\
\hline 448.8 & 646.9 & 198.1 & 23.3 & 33.6 & 10.3 & |الإســكندرية & جميزة: \\
\hline 587.5 & 592.8 & 5.3 & 31.4 & 31.7 & 0.3 & أســـوان & سدس \\
\hline 529.1 & 603.6 & 74.5 & 26.8 & 30.6 & 3.8 & |الإسـكندرية & جميزة9 \\
\hline 318.6 & 475 & 156.4 & 17.8 & 26.6 & 8.7 & دميــــاط & سخا 9 س \\
\hline 31.5 & 385.8 & 354.4 & 1.6 & 19.9 & 18.3 & المنيـــا & سخا rq \\
\hline 11.5 & 262.2 & 250.7 & 0.8 & 17.5 & 16.7 & بور سـعيد & سخا rq \\
\hline 293.3 & 331.9 & 38.6 & 13.8 & 15.6 & 1.8 & الأقصر & سخا 9 \\
\hline-1416.1 & 113.3 & 1529.4 & -83 & 6.6 & 89.6 & قن & جيزة 171 \\
\hline-71.4 & 103.5 & 174.9 & -3.9 & 5.6 & 9.5 & كفر الثـيخ & سخا ال7 \\
\hline-6.4 & 10.6 & 17 & -3.2 & 5.3 & 8.5 & شمال سيناء & بلدى بل \\
\hline-5.4 & 65.1 & 70.4 & -0.4 & 4.5 & 4.9 & الو ادى الجـديد & جيزة ـ17 \\
\hline 41.3 & 65.6 & 24.3 & 2.5 & 4 & 1.5 & الســـيس & سخا 9 \\
\hline-504 & 53.7 & 557.7 & -29.3 & 3.1 & 32.4 & الفيــوم & جيزة 1717 \\
\hline 2 & 46 & 43.9 & 0.1 & 2.9 & 2.7 & قن & جيزة 100 \\
\hline 22.4 & 34.8 & 12.4 & 1.5 & 2.4 & 0.8 & |الو ادى الجديد & سوهاج r \\
\hline 37.3 & 45.3 & 8 & 1.9 & 2.3 & 0.4 & المنيـــا & بنى سويف r \\
\hline 36.2 & 40 & 3.8 & 1.7 & 1.9 & 0.2 & أســيوط & سوهاج 1 \\
\hline 0 & 6.9 & 6.9 & 0 & 0.5 & 0.5 & الثـــــية & سخام \\
\hline 0 & 7.8 & 7.8 & 0 & 0.4 & 0.4 & بنى سويف & سدس \\
\hline 0.2 & 0.6 & 0.4 & 0 & 0.1 & 0 & جنوب سيناء & جيزة 171 \\
\hline 1.1 & 2.4 & 1.3 & 0.1 & 0.1 & 0.1 & القاهــــرة & سخا rq \\
\hline 0 & 1.2 & 1.2 & 0 & 0.1 & 0.1 & البحـيرة & جميزة| \\
\hline-34487.8 & 0 & 34487.8 & 0 & 0 & 1877.4 & \multicolumn{2}{|c|}{ الأصناف الاخرى } \\
\hline 1835.3 & 55742.8 & 53907.5 & -53.4 & 2929.4 & 2982.8 & \multicolumn{2}{|c|}{ جملة } \\
\hline
\end{tabular}

المصدر: جمعت وحسبت من بيانات وزارة الزراعة واستصلاح الأراضى، الادارة المركزية للإقتصاد الزراعى، نشرة

الاحصاء الزر اعى، أعداد مختلفتة.

Fayoum J. Agric. Res. \& Dev., Vol. 30, No.1, January, 2016 
10

جدول (• 1): نتائج البرمجة الخطية لدالة الهـف لمعظمة الانتاج لمحصول القمح خلال الفترة (r+1r-r+11)

\begin{tabular}{|c|c|c|c|c|c|c|c|}
\hline الف اردب الفرق & الألف اردبت & الف الآلىى & الف فذان & الألف فلقاحة & الف الحالية & المحافظة & الصنف \\
\hline 3452.1 & 4360.3 & 908.1 & 190.6 & 240.7 & 50.1 & كفر الثـيخ & جيزة 17/ \\
\hline 264.3 & 541.8 & 277.5 & 14.5 & 29.7 & 15.2 & دميـاط & جيزة 171 \\
\hline 0.0 & 1.4 & 1.4 & 0.0 & 0.1 & 0.1 & القاهــرة & جيزة 171 \\
\hline 7.6 & 192.8 & 185.2 & 0.6 & 16.1 & 15.5 & مطــروح & جيزة 171 \\
\hline 0.0 & 281.5 & 281.5 & 0.0 & 15.8 & 15.8 & بور سعيد & ســـا 9 س \\
\hline 65.9 & 89.6 & 23.7 & 3.6 & 4.9 & 1.3 & الســـيس & سـخا 9 س \\
\hline 1124.9 & 1133.4 & 8.5 & 56.3 & 56.8 & 0.4 & أســـوان & ســا 9 س \\
\hline 0.0 & 1.3 & 1.3 & 0.0 & 0.5 & 0.5 & شمال سيناء & ســا 94 \\
\hline 2.0 & 4.0 & 1.9 & 0.2 & 0.4 & 0.2 & جنوب سيناء & ســا بـ \\
\hline 1864.7 & 2431.6 & 566.9 & 103.0 & 134.3 & 31.3 & النوباريــة & ســا \\
\hline 7790.6 & 7809.1 & 18.5 & 339.6 & 340.4 & 0.8 & البحـيرة & ســا \\
\hline 1363.3 & 1503.6 & 140.4 & 71.4 & 78.8 & 7.4 & الإسكندرية & جميزة 9 \\
\hline 3087.4 & 3114.5 & 27.1 & 135.0 & 136.2 & 1.2 & المنوفيـة & جميزة . 1 \\
\hline 8771.7 & 8794.6 & 22.9 & 426.2 & 427.3 & 1.1 & الثــرقية & جميزة V \\
\hline 1076.5 & 1140.3 & 63.8 & 54.7 & 58.0 & 3.2 & القليوبيـــــا & جميزة V \\
\hline 3156.5 & 3990.5 & 833.9 & 162.2 & 205.0 & 42.9 & أســيوط & بنى سويف \\
\hline 3587.5 & 3662.1 & 74.5 & 189.1 & 193.1 & 3.9 & الفيـــوم & بنى سويف \\
\hline 2630.3 & 2672.7 & 42.4 & 134.3 & 136.4 & 2.2 & بنى سويف & بنى سويف \\
\hline 2974.1 & 3227.5 & 253.3 & 142.8 & 154.9 & 12.2 & الغربيـــة & مصر I \\
\hline 5349.3 & 6064.5 & 715.1 & 263.9 & 299.2 & 35.3 & الدقهليــة & مصر 1 \\
\hline 783.3 & 971.5 & 188.2 & 42.6 & 52.8 & 10.2 & الإسماعيلية & مصر 1 \\
\hline 859.7 & 977.7 & 118.0 & 37.9 & 43.1 & 5.2 & الجيـزة & مصر I \\
\hline 4568.4 & 4701.7 & 133.4 & 223.7 & 230.2 & 6.5 & المنيـــا & مصر 1 \\
\hline 3365.0 & 3475.8 & 110.9 & 174.1 & 179.8 & 5.7 & ســوهاج & مصر 1 \\
\hline 1725.5 & 2094.9 & 369.4 & 99.8 & 121.2 & 21.4 & الجدادى & مصر 1 \\
\hline 2114.7 & 2178.2 & 63.5 & 108.0 & 111.3 & 3.2 & قن & مصر r \\
\hline 779.9 & 793.9 & 14.0 & 42.7 & 43.5 & 0.8 & الأقصـــر & مصر r \\
\hline-56585.5 & 0.0 & $\begin{array}{c}56585 . \\
5\end{array}$ & 0.0 & 0.0 & 3066.1 & \multicolumn{2}{|c|}{ الأصناف الاخرى } \\
\hline 4179.8 & 66210.8 & $\begin{array}{c}62031 . \\
0\end{array}$ & -49.2 & 3310.5 & 3359.7 & \multicolumn{2}{|c|}{ الجملة } \\
\hline
\end{tabular}

الاحصاء الزر اعى، أعداد مختلفتة.

Fayoum J. Agric. Res. \& Dev., Vol. 30, No.1, January, 2016 


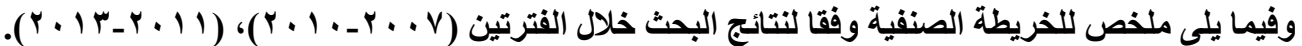

\begin{tabular}{|c|c|c|c|c|c|c|c|c|}
\hline \multicolumn{4}{|c|}{$\left(r+1 r_{-} r+11\right)$} & \multicolumn{4}{|c|}{$(2007-2010)$} & \multirow[b]{2}{*}{ المحافظة } \\
\hline الانتاجمة & |تدنيةٌ الاحتياجاتة & معظمة صافى العائد & الصنف & معظمة & |تلنية الاحتياجات & معظمة صافى العائد & الصنف & \\
\hline جميزة 9 & جمبزة · 1 & جميزة 9 & جميزة 9 & جمبزةV، 9 & جبزة 171 & جمبزة:V، 9 & جميزة9 & الإسـكندرية \\
\hline مصر 1 & مصر Y' & مصر 1 & مصر 1 & سخا & جبزة & سخا & جميزة. & الإسماعيلية \\
\hline مصر r & سذا بو & جيزة 171 & سـا ال7 & سخا זو & جيزة 100 100 & سخا بو & سخا بو & الأقصر \\
\hline سخا آ7 & جميزة V & مصر 1 & مصر ' & سخامةهم، & سخيزة؛ه، & سخبزة)، & سخا ؟9 & البحـيرة \\
\hline مصر 1 & جميزة: V & جميزة · & مصر Y & سخا & سدس & سخا & سخا & الجـيزة \\
\hline مصر 1 & مصر 1 & مصر r & سـخا به & 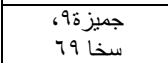 & سخا rq & 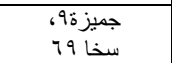 & سخا 99 & الدقهليـة \\
\hline سـخا 9 & جيزة 171 & سـخا 9 & جمبزة V & سخا بو9 & بلدى & سخا 9 & سخا 9 & السـويس \\
\hline جميزة V & سـا ؟ 9 & جميزة V & جميزة 11 & 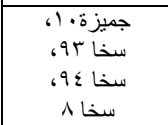 & 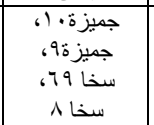 & 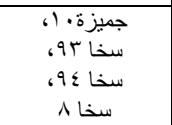 & جميزة. & الثـرقية \\
\hline مصر 1 & مصر 1 & مصر 1 & مصر 1 & سخا rq & سخا (7)، & سخا rq & جميزة. & الغربيـة \\
\hline بنى سويف 0 & جميزة 9 & مصر 1 & جيزة 171 & 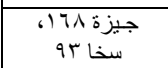 & 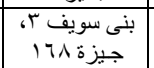 & 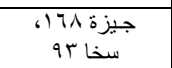 & سدس & الفيوم \\
\hline جيزة 171 & جيزة 1711 & جيزة 171 & مصر 1 & سخا 9 & جبزة 171 & سخا 9 & سخا ب99 & القاهــرة \\
\hline جميزة V & سـا 9 & مصر 1 & جميزة 11 & سخا & جبزة 171 & سخا & جمبزة: & القليوبيــة \\
\hline جميزة · 1 & جميزة V & سدس r| & مصر 1 & جيزة 171 & سخا 9 & جبزة 171 & جيزة 171 & المنوفيـة \\
\hline مصر 1 & سدس 1 & مصر 1 & سـخا ؟9 & 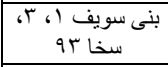 & 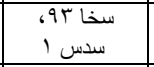 & بنى سويف با ب، & بنى سويف r & المنيــا \\
\hline سـخا ؟9 & مصر r & سـخا ؟9 & مصر 1 & جيزة 171 & سخازة"Vا، & جيزة 111 & جيزة 1717 & النوباريــة \\
\hline مصر 1 & بنى سويف 1 & مصر 1 & سـخا به & 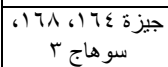 & بنى سويف 1 & 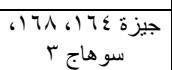 & سخا ؟9 & الو ادى الجديد \\
\hline سـخا بـ9 & سـخا بra & جيزة 171 & بنى سويف 1 & سدس & جبزة 171 & سدس & سدس & أســوان \\
\hline بنى سويف 1 & جيزة 171 & بنى سويف 1 & بنى سويف ؛ & سخاع، عاى، & 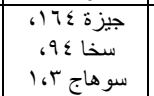 & سخا عاج 1 سو، & سخا ؟ & أسيـوط \\
\hline بنى سويف ع & مصر r & مصر 1 & سـخا بـ9 & جيزة 1ـ 1، & |لدى، جيزة 17 171 & بلدى، جيزة 17 1، & سخا 79 & بنى سويف \\
\hline سـخا بو & سـخا بو & سـخا 9 & سـخا & سخا با9 & جيزة 171 & سخا بو9 & سخا 9 & بور سـعيد \\
\hline سـخا بو9 & سـخا بra & سـخا بra & جيزة 171 & جيزة 171 & جبزة 171 & جيزة 171 & جيزة 171 & جنوب سيناء \\
\hline جيزة 171 & سخا ع 9 & جيزة 171 & مصر 1 & سخا 9 & جبزة 171 & سخا 9 & جمبزة" & دمبـاط \\
\hline مصر 1 & مصر 1 & مصر 1 & سـخا بو & سدس & بنى سويف ب'، & سدس & سدس | & سـوهاج \\
\hline سخا بو & سخا 9 & سخا 9 & مصر 1 & بلدى & بلدى & بلدى & سخا 9 & شمال سيناء \\
\hline مصر r & سدس 1 & سدس 1 & سدس r| & جيزة 100 19171، 171 | & جيزة 141 & جيزة 100، 171، 17، & سدس & قنــ \\
\hline جيزة 141 & جيزة 171 & سدس r| & مصر r & جيزة ال1 آ، & سخا rq & جيزة الب ال، & جميزة & كفر الثـيخ \\
\hline جيزة 171 & جيزة 171 & جيزة 171 & جيزة 1717 & جيزة عا 17 & جيزة عا 17 & جيزة £17 & جيزة عا 17 & مطروح \\
\hline
\end{tabular}

المصدر: جمعت وحسبت من بيانات وزارة الزراعة واستصلاح الأراضى، الادارة المركزية للإقتصاد الزراعى، نشرة الاحصاء الزر اعى، أعداد مختلفتّة.

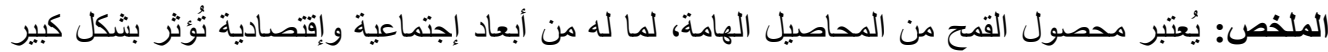

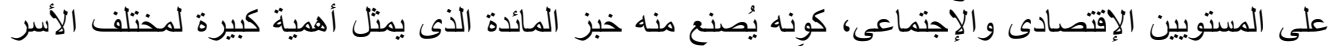

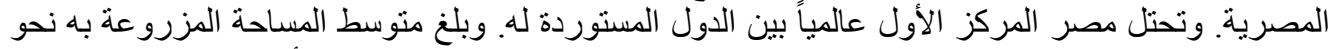

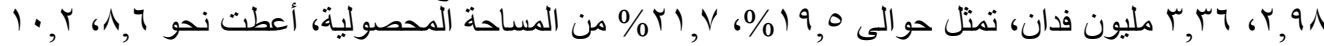

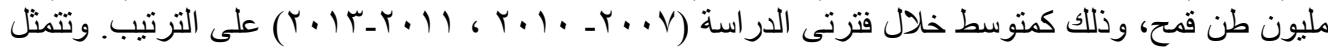

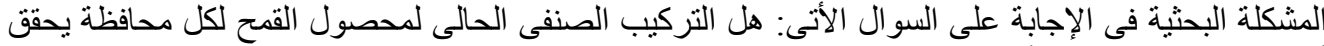

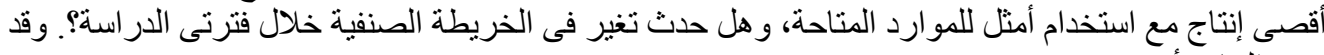

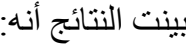

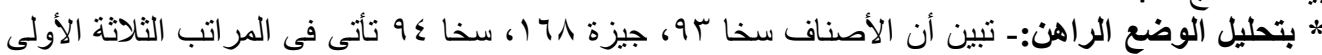

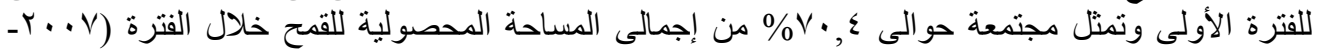

Fayoum J. Agric. Res. \& Dev., Vol. 30, No.1, January, 2016 
IV

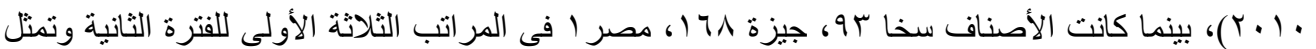

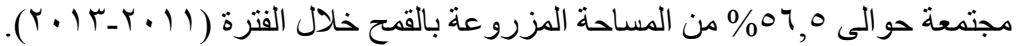

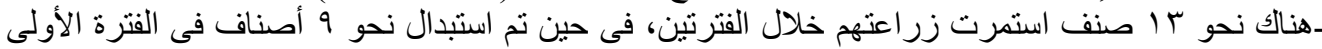

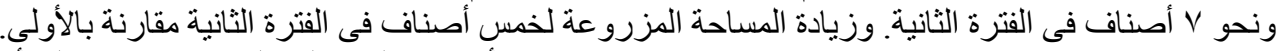

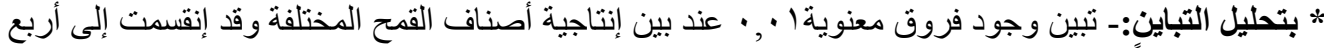

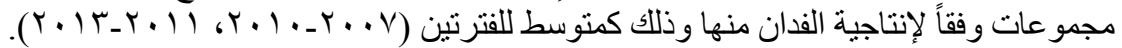

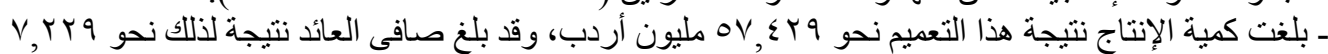

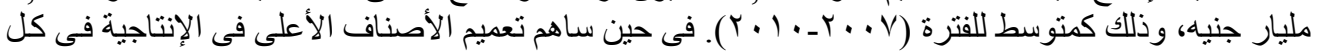

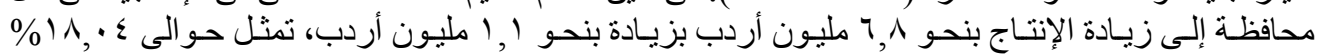

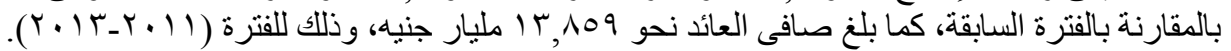

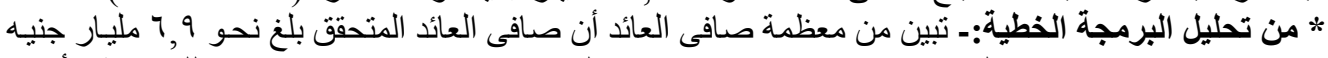

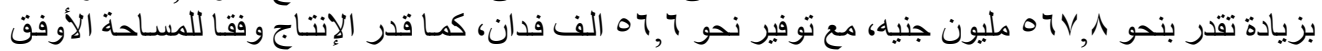

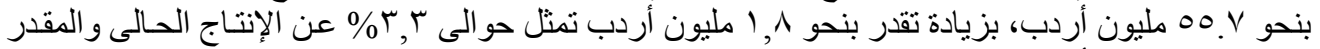

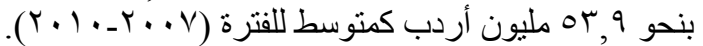

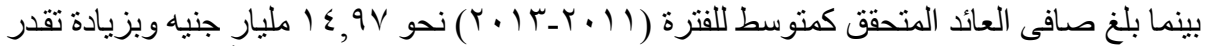

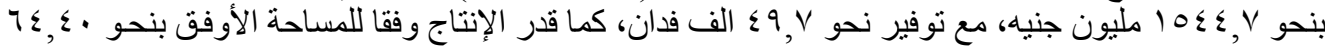

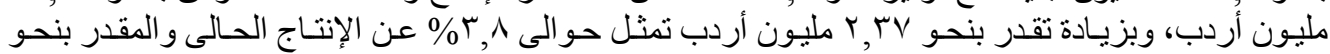

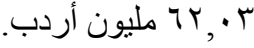

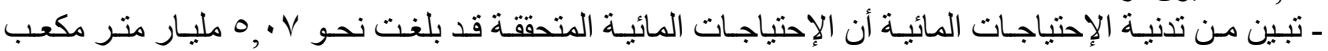

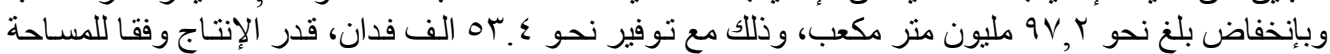

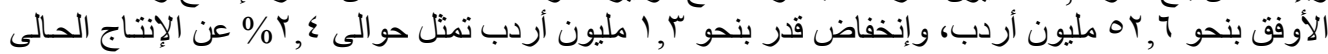

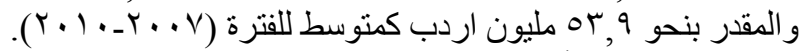

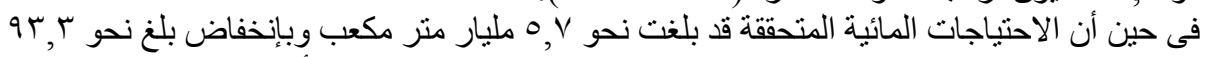

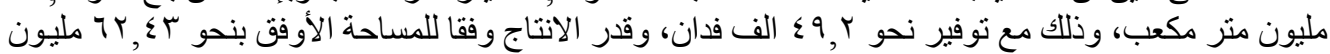

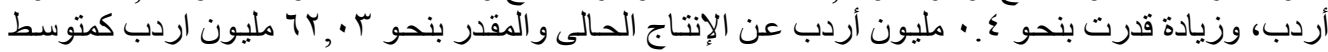

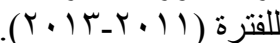

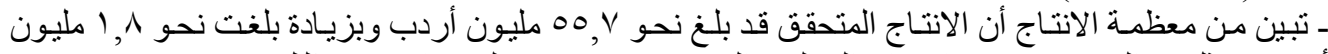

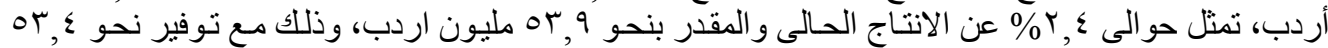

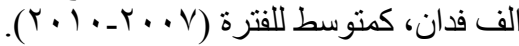

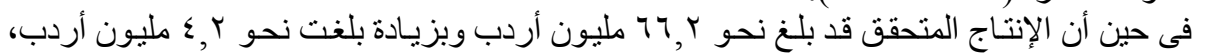

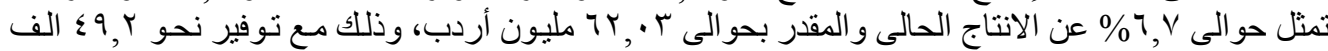

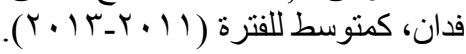

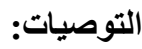

توصى الدراسة بما يلى: عمل توعية إرشادية للمز ارعين بهذف تبنيهم لزر اعة أصناف القمح الأعلى إنتاجية بكل التبل

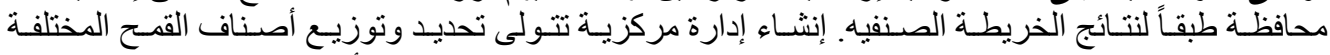

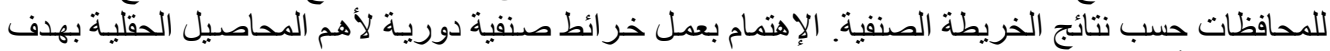

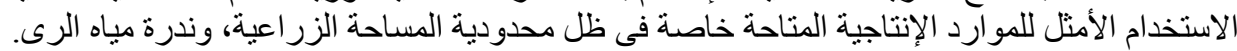

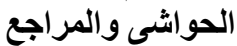
(1) وز ارة الزراعة واستصلاح الأراضى، الادارة المركزية للإقتصاد الزراعى، نشرة الاحصاء الزر اعي، أعداد مختلفة.

$(\checkmark)$ Wheat including spelt and meslin, unmilled [SITC Rev.1 code 041]

( $\left.{ }^{(}\right)$http://comtrade.un.org/db/mr/daCommoditiesResults.aspx?px=S1\&cc=041

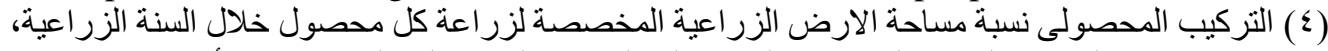

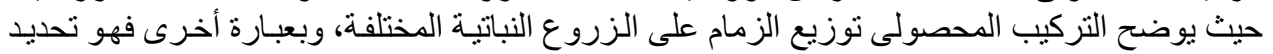
للمساحات التى يتم زر اعتها بمختلف الزروع النى النباتية على مدار العام.

Fayoum J. Agric. Res. \& Dev., Vol. 30, No.1, January, 2016 
11

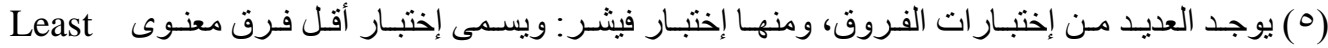
Significant Difference test (L.S.D)

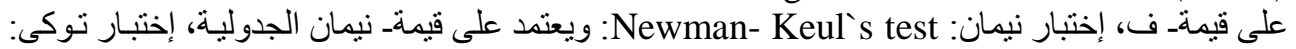

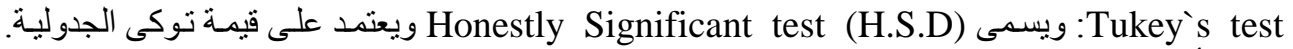

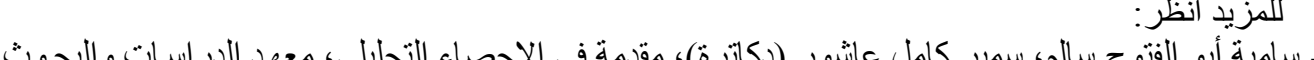

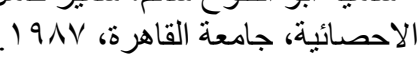

- R. Johnson and D. Wichern, Applied Multivariate Statistical Methods, Third Edition, Prentice Hall, 1992.

- D.C. Montgomery, Design and Analysis of Experiments, Third Edition, John Wiley \& Sons, 1991 .

- L.S. Nelson, Factors for the Analysis of Means, Journal of Quality Technology, 6, 1974.

- P.R. Nelson, A Comparison of Sample Sizes for the Analysis of Means and the Analysis of Variance, Journal of Quality Technology, 15, 1983.

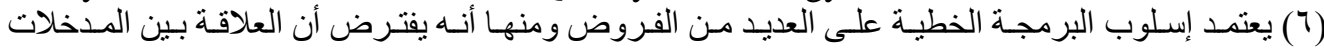

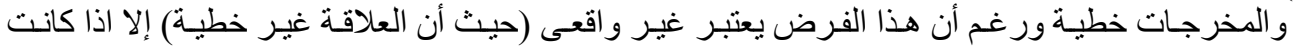

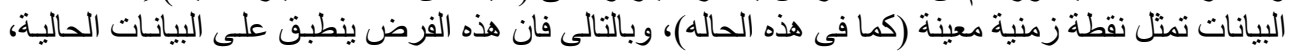

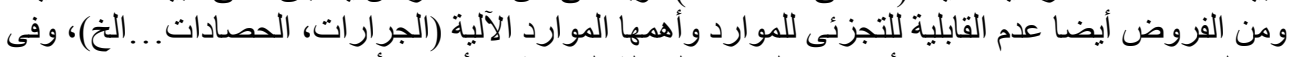

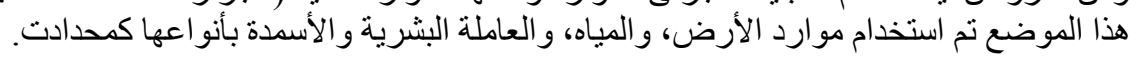

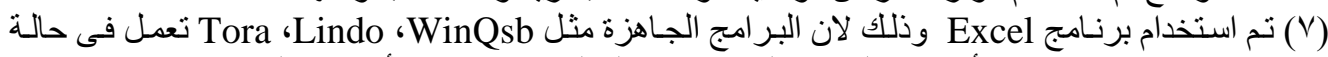

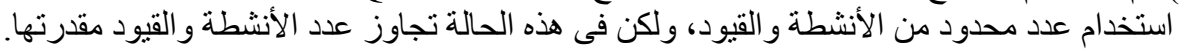

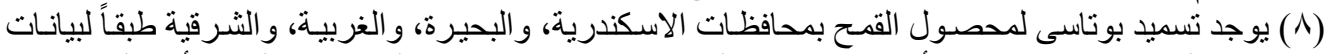

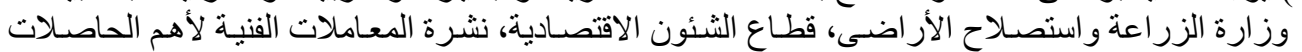
الز الزية، أعداد مختلفة. (9) بدأ إنتاج بعض أصناف مانف القمح كالتالى:

\begin{tabular}{|c|c|c|c|c|c|c|c|c|c|}
\hline السنة & الصنف & السنة & الصنف & السنة & الصنف & السنة & الصنف & السنة & الصنف \\
\hline $19 \vee \wedge$ & سخا M & $19 \vee \wedge$ & جيزة 10人 & $19 V A$ & جيزة 10V & $19 V V$ & جيزة 107 & 1971 & جيزة 100 \\
\hline 1919 & جيزة rا7 & 1919 & جيزة rا 1 & 1919 & سخا بr9 & 191. & سخا 79 & 191. & سخا וT \\
\hline 1990 & سدس 1 & 1990 & جيزة VI 17 & $199 \varepsilon$ & جمبزة 1 & 199. & جيزة 170 & 1919 & جيزة ـال 17 \\
\hline 1997 & سدس 9 & 1997 & سدس & 1997 & سدس V & 1997 & سدس 7 & 1990 & سدس ع \\
\hline 1990 & بنى سويف r & 1991 & سوهاج " & $19 V A$ & سو هاج r & $19 \vee \wedge$ & سو هاج 1 & $19 V \wedge$ & بنى سويف 1 \\
\hline
\end{tabular}

Source: http://aradina.kenanaonline.com/photos/1234179379

\begin{tabular}{|c|c|c|c|}
\hline مناطق الزراعة & الصنف & اصنتاف القمح حالتالى: & طق زراعن \\
\hline منطقة النوبارية - الأراضى & 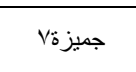 & شمال الدلتا - وسطوجنوب الدلتا - مصر العليا والارضى الجديدة & 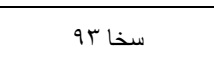 \\
\hline وسط وجنوب الدلتا & 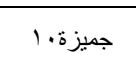 & شمال الدلتا - وسط وجنوب الدلتا - مصنر اللوسطى - مصر العليا - الأراضى & 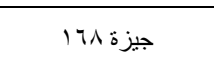 \\
\hline 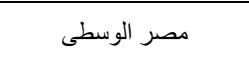 & سوسف عا، بنى & شمال الدلتا - وسط وجنوب الدلتا & جميزة9، (1)، سخا §9 \\
\hline \multirow[t]{2}{*}{ مصر العليا } & 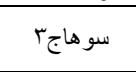 & 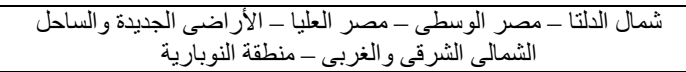 & | سـس | ( \\
\hline & & مصر الوسطى - مصر العليا & بنى سويف ا ، 0، \\
\hline
\end{tabular}

Source: http://www.agricultureegypt.com/

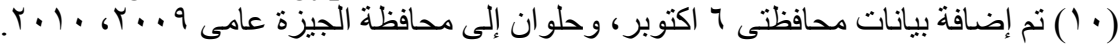

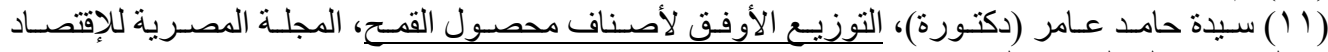

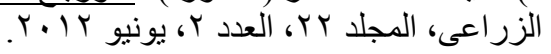

Fayoum J. Agric. Res. \& Dev., Vol. 30, No.1, January, 2016 
19

\section{COMPARETIVE STUDY FOR THE BEST VARIETY MAP OF WHEAT CROP IN EGYPT.}

Dr. Sayda Hamed Amer

Economic Research Institute
Dr. Hussein M.A. Rostom

Food Technology Research Institute

\section{Summary:}

Wheat is considerd one of the most important crop from the social and economic view, as it considerd the main raw material in bread processing. Average cultivated area of wheat reach about 3.36 and 2.98 million feddan represent about $21.7 \%$ and $19.5 \%$ of the total cultivated area which produce about 8.6 and 10.2 million ton wheat as an average for the period (2007-2010, 2011-2013) respectively.

Variance analysis showed that:- There was significant varience between the different wheat varieties and it was divided to 4 groups according the productivity as an average for the two period (2007-20010, 2011-2013).

- Amount of production reach about 57.4 million ardab, and the net return reach about 7.2 milliar L.E as an average for the period (2007-2010). As a result of generalization. Mean while generalization of high varieties in each governorate, share in increasing production by about 6.8 million ardab by increasment reach 1.1 million ardab represenl about $18.04 \%$ in comparing by the pervious period, net revenu reach about 13.859 milliar L.E for the period (2011-2013).

linear programming results show that:- Maximizing of net return illustrat that the net return realized about 6.9 milliar L.E by increasment reach about 567.8 million L.E and saving about 56.6 thousand feddan. According to the best area production was accounted to about 55.7 million ardab by increasment reach 1.8 million ardab represent about 3.3\% in comparing to the present production which amounted to 53.9 million ardab as an average for the period (2007-2010), While net return reach about 14.97 milliar L.E by increasment reach 1544.7 million L.E and saving about 49.7 thousand feddan, also production was assumed, according to the best area by 64.40 million ardab, and increasment reach 2.37 million ardab represent about $3.8 \%$ in comparing to the present production evaluated by 62.03 million ardab. In case of minimizing the realized water require ment evaluated by 5.07 million $\mathrm{m} 3$ by decreasing reach about 97.2 million $\mathrm{m} 3$ and saving about 53.4 thousand feddan. Production was evaluated according to the best area by 52.6 million ardab by decreasing evaluated by 1.3 million ardab represent about $2.4 \%$ in comparing to the present production which evaluated by 53.9 million ardab as an average for the period (2007-2010), while the realized water require ment reach 5.7 milliar $\mathrm{m} 3$ by decreasment reach 93.3 million $\mathrm{m} 3$ and saving 49.2 thousand feddan, and the production was calculated according to the best area by 62.43 million ardab as an average for the period (2011-2013). Maximizing of production illustrate that the realized production reach 55.7 million ardab

Fayoum J. Agric. Res. \& Dev., Vol. 30, No.1, January, 2016 
r.

which an increasment reach 1.8 million ardab represent $2.4 \%$ in comparing to the present production evaluated by 53.9 million ardab and saving about 53.4 thousand feddan as an average for the period (2007-2010), while the realized production reach 66.2 million ardab by increasment reach 4.2 million ardab, represent about $6.7 \%$ in copmaring to the present production estimated by 26.03 million ardab with saving 49.2 thousand feddan as an average for the period (2011-2013).

The study recommend the following:-Conducting exetension awarness for farmers to illiustrate cultivating varieties of high productivity in each governorate according to the results of the variety map.

- Establishing central administrate detreminate and distribute the different varieties of wheat for the governorates according to the variety maps results.

- Getting attension for conducting periodically variety maps for the most important filed crops to realize the best use of the available production resources especially under the restrected cultivated area and rare of water irrigation. 